THE additions to the Zoological Society's Gardensiduring the past week include a Vervet Monkey (Cercopitheius lalandii) from South Africa, presented by Mrs. E. L. Francis ; a Chacma Baboon (Cynocephalus porcarius) from South Africa, presented by the 4th Co. Arny Service Corps; an Anubis Baboon (Cynocephalus anutis) from West Africa, presented by $\mathrm{Mr}$. R. I). Whigham; a Formosan Deer (Cervus taëzanus?) from China, presented by Captain Percy Scott, - H.M.S. Terrible; three Herring Gulls (Larus argeniatus), European, presented by Mr. F. W. Hunt; a Land Rail (Crex pratensis), British, presented by Miss Elsie E. IIutton; a Schmidt's Monkey (Cercopithecus schmidti) from East Africa, a Black-cheeked Monkey (Cercopithecus melanogenys) from West Africa, two Rhesus Monkeys (Macacus rhesus), an Indian Python (Python molurus) from India, a Brown Maca(que (Macacus arctoides) from Burmah, an Amphiuma (Amphiuma means) from North America, a Lion Marmoset (Midas rosalia) from Southeast Brazil, two Eyras (Felis eyra) from South America, deposited.

\section{THE SCIENTIFIC AND TECHNICAL}

\section{EXHIBITS AT THE ROYAL PHOTOGRAPHIC} SOCIETYS EXHIBITION.

THIS section of the Royal I'hotographic Society's exhibition appears to be rather smaller than on the two previous occasions, that is, since the larger accommodation of the New Gallery made it pussible to represent adequately this side of photographic work. W'e hope that this is not an indication that the section is receiving less attention and is likely to suffer extinction, the fate that we regret to observe has overtaken the apparatus section, except, indeed, so far as concerns the trade stalls and a few cxhibits that appear to be out of place in any of the existing departments.

The most striking novelty in the Gallery is a "parallax stereogram" show'n by Mr. F. E. Ives. No details are furnished, but we believe that the photograph is taken by means of a lens of large diameter obscured except for two apertures, one on each side, so that it acts in a similar way to the two lenses of the ordinary stereoscope camera, but that the two images are superimposed. In front of the sensitive plate there is placed a screen with vertical lines on it, alternately opaque and transparent, at such a distance that each image will impinge upon the plate in narrow, vertical strips and in the shadows of the opaque lines cast by the light transmitted by the other opening in the lens. The two images are thus received on the plate in narrow, alternating strips. For viewing, the eyes take the place of the openings in the lens, the lined screen remaining in position to keep the two images separate. The correct position for the eyes is indicated by two holes in a board, no other apparatus being necessary. The effect is perfect.

The only example of colour photography by the Lippmann process is a photograph of the spectrum of the arc light by $\mathrm{Mr}$. Edgar Senior. This is an improvement on Mr. Senior's previous noteworthy results, being taken with a narrower slit, but still the colours shown are not quite the same as those which one sees in the direct spectrum. It seems not unlikely that the differences are inherent in the process. Of other prints in colour, Mr. Brewerton contributes some in which the blue print is in Prussian blue, and the red and yellow superposed carbon prints, and Miss Acland some copies of miniatures by a modification of the Sanger Shepherd three-film process. These results are admirable, but they are not convincing. It would be better if an object were used less valuable than a precious miniature and more convenient than a landscape, so that the object and the copy could be exhibited side by side. It is well known that very good results can be obtained ; we want now to see how near they are to perfection.

Mr. Hort Player exhibits some splendid examples of his method of copying engravings by superposition. The ordinary relative positions of the engraving and the sensitive paper are reversed, the light passing through the sensitive paper before it lluminates the engraving. A yellow screen is used, and potass ium iodide is added to the developer. The whiteness of the NO. I 7 I 9, VOL. 66] ground, the blackness of the lines and the sharpness of the detail are excellent.

Photomicrography is well represented. The most notable examples are a series of photomicrographs taken in connection with the bacterial treatment of sewage, exhibited by Dr. Clowes. The enlargements vary from about natural size up to three thousand diameters. These fifty or more photographs may well be accepted as a model of what this kind of technical work should be. Mr. Ives has twelve photomicrographs made with a small and simple apparatus that is not described. The results would do credit to any apparatus, and show what may be done by care and skill without elal,orate conveniences. Among the other work of this class that deserves commendation is a series of microphotographs of etched alloys by Mr. Earnest A. Lewis.

Astronomical and spectroscopic photography is well represented by very fine work from Sir Norman Lockyer, Captain Hills, the Greenwich Observatory and others. Some of the spectra have no wave-length scale attached, or any other indication of the part of the spectrum represented, and others bear no indication of the facts sought in their preparation or of the facts that the spectra demonstrate. If a little information of this kind were invited by the Society's officers and incorporated in the catalogue, the exhibits would gain vastly in interest. This want of information is also manifest in the "multiple lightning flash," fourfold, by MIr. J. Howden Wilkie, presumably taken with a swinging camera, and in other cases.

There are many other exhibits that deserve more than a passing mention. Snow formations, huge "caps" and "mushrooms" are illustrated by Mr. Vaughan Cornish (see p. 453 of this volume). Balloon photographs, Röntgen-ray work, the photography of animals and meteorological photography are represented by collections of good and in some cases unique examples.

\section{THE BRITISH ASSOCIATION AT BELFAST. SECTION K.}

Botaxy.

Opexing AdDress by l'rof. J. Reynolins Green, M.A., Sc.D., F.R.S., PRESIDEN'T OF THE Secrion.

THE visits of the British Association to a particular city recur with a certain irregular frequency and bring with them a temptation to the President of a Section to dwell in his opening Address on the progress made in the science associated with that Section during the interval between such consecutive visits. This course possesses a certain fascination of its own, for it enables us to realise how far the patient investigations of years have ultimately led to definite advances in knowledge and to appreciate the difficulties that have involved disappointments, and that still have to be surmounted. We like to look back upon the struggles, to record the triumphs, to deplore the failures and to brace ourselves for new efforts. The oppcrtunity afforded hereby for criticism of methods, for reconsideration of what have been held to be fundamental principles, for the laying down of new lines of work based upon longer experience, shows us how desirable such a periodical retrospect may be.

Standing as we do almost at the threshold of a new century, it seems particularly advisable that we shall occupy our thoughts with some such considerations to-day. I do not wish, however, so much to dwell upon the past and to lead my hearers to rest in any way satisfied with the achievements of the last century, phenomenal as they have been, as to direct attention to the future and to place before you some of those problems which at the opening of the twentieth century we find awaiting investigation, if not solution.

I can only attempt to deal with a small portion of the botanical field. These are the days of specialisation, and when anyone is said to be a botanist, the question which arises at once is, Which particular section of botany is he associated with? The same principle of subdivision which cut up the old subject of Natural History into \%oology, Botany and Geology has now gone further as knowledge has increased, and three or perhaps four departments of botany must be recognised, eack demanding as much study as the whole subject seemed to only fifty years ago. I shall therefore confine my remarks to-day to the field of vegetable physiology.

I should like at the outset to recommend this section of botanical work to those of the younger school of botanists who 
are contemplating original research. To my mind the possibilities of the living organism as such present a fascination which is not afforded by the dry bones of morphology or histology ; valuable as researches into the latter are, they seem to me to derive their importance very largely from the past, from the possibility of indicating or ascertaining the line of descent of living forms and the relation of the latter to their remote ancestors. The interest thus excited seems to me to be rather of an academic character when compared with the actual problems of present-day life, its struggles, triumphs and defeats in the conflict for existence waged to-day by every living organism. The importance of the study of physiology as bearing upon the problems of the morphologists has, I need hardly say, been fully recognised by the workers in that field. I may quote here a sentence or two from the Address of one of my distin guished predecessors, who said at Liverpool, "There is a close relation between these two branches of biology, at any rate to those who maintain the Darwinian position, for from that point of view we see that all the characters which the morphologist has to compare are, or have been, adaptive. Hence it is impossible for the morphologist $t$ ) ignore the functions of those organs of which he is studying the homologies. To those who accept the origin of species by variation and natural selection there are no such things as morphological characters pure and simple. There are not two distinct categories of characters-a morphological and a phýsiological category-for all characters alike are physiological."

But apart from the considerations of the claims of vegetable physiology based upon its own intrinsic scientific value and the interest which its problems pussess for the worker himself, and upon the place accurded to it as its relationship to morphology, it must, I think, be recognised as being of fundamental economic importance, especially in these times of agricultural depression. For many years now it has been recognised that agriculture is based upon science ; that it involves indeed properly the application of scientific principles to the cultivation of the soil. But when we look back upon what has passed for agricultural science since the alliance between the two has been admitted, we can. not but recognise how lamentably deficient in breadth it has been. The chemical composition of the soil and subsoil has been investigated with some thoroughness in many districts of the country. The effect of its various constituents on the weight and quality of the crops cultivated in it has been exhaustively inquired into, and a considerable amount of informa. tion as to what minerals are advantageously applied to the soil in which particular plants are to be sown has been acquired. A kind of empirical knowledge is thus in our possession, in some respects a very detailed one, quantitative as well as qualitative records being available to the inquirer. But elaborate as have been the researches in these directions, and costly and troublesome as the investigations have been, they have been hardly, if at all, more than empirical. Till quite recently the physiological idiosyncrasies of the plants round which all these inquiries centred were almost entirely ignored. No serious attempt was made to ascertain the way in which a plant benefited by or suffered from the presence of a particular constituent of the soil. What influence, for instance, has potassium or any of 'its compounds upon the general metabolism of the plant? Ioes it affect all its normal nutritive processes, or does it specially associate itself with some particular one? If so which one, and how does the plant respond to its presence or absence by modifying its behaviour? So with phosphorus again ; hardly any investigation can be made into the nutritive processes of a plant without this element becoming more or less prominent. In soine cases the empirical results already referred to show an enormous influence on the crop exerted by soluble phosphates in the soil or the manure applied to it. But what can yet be said as to the rôle played by phosphorus or by phosphates in the metabolic processes in the plant? Further, how do different plants show different peculiarities in their reactions to these various constituents of the soil? For the advance of agriculture the study of the plant itself must now be added to the study of the soil. The fact that it is a living organism possessing a certain variable and delicate constitution, responding in particular ways to differences of environment, capable of adapting itself to a certain extent to its conditions of life, dealing in particular ways with different nutritive substances, must not only be recognised, but must be the basis for the researches of the future. which will thus supplement and enlarge the conclusions derived

No. 1719 , voL. 66$]$ from those of the past, in some respects correcting them, in others establishing them on a firmer basis.

In pressing upon the younger school of botanists the import. ance of this line of research, I do not wish to minimise the difficulties that accompany it. Difficulties of method assume considerable magnitude, for we have here no question of section cutting and microscopic examination. Vegetable physiology is allied very closely to other sciences, and research into its mysteries involves more than a preliminary acquaintance with them. Fispecially must one point out the importance, indeed the necessity, of acquaintance with a certain range of organic chemistry and with chemical methods of work. In certain directions, too, physics are as much involved as chemistry in others. The bearing of these sciences in particular directions will be referred to later.

I fear another obstacle stands at the threshold of research which looks sufficiently formidable. The so-called fundamental facts of vegetable physiology have been laid down with sufficient dogmatism in text-books by many writers whose names carry with them such weight that it appears almost beresy to question their statements. IVe have been content to accept many things on the authority of the great workers of the past, with the result that the advance of knowledge has been hindered by such acceptance of what were deemed facts, but were really inaccuracies. We may refer, for instance, to the statement made by Boussingault, and accepted by most botanists ever since his time, that the absorption of carbon dioxide from the air takes place by means of solution in the cuticle of the epidermal cells of plants and thence passes by diffusion to the seats of photo. synthesis. Only comparatively recently has this been shown to be erroneous. If, however, it is once recognised that authority is fallible, this apparent obstacle becomes the opposite. The more evident questions have not yet been solved, leaving only the more difficult ones for the present-day worker.

Recognising the importance of work in this field, and realising that with the advent of a new century new departures must be taken, I have thought I might venture to direct the thoughts of my hearers, many of whom I may call my colleagues, to the present position of certain problems which have lnng been the subjects of speculation and which offer the pru spect, if not of complete solution, at any rate of considerable advance if investigated by modern methods.

I turn first to a few questions connected with the nutritive problems of plants in general.

There are several theories abroad as to the progress of events during photosynthesis, none of which can be regarded as entirely satisfactory. For many reasons it seems desirable that this question shall be thoroughly investigated in the light of the present condition of both chemical and physical science. I may perhaps venture to recall to you the principal hypotheses of carbohydrate formation which have been advanced, so that its present position may be properly appreciated.

The view that has met with the widest acceptance is that 0 Baeyer. On his hypothesis the carbon dioxide absorbed is decomposed under normal conditions to yield carbon monoxide and oxygen; a corresponding and coincident decomposition of water leads to the production of free hydrogen and oxygen. The oxygen from both sources is exhaled, while the carbon monoxide and hydrogen combine to form formaldehyde. The formaldehyde gives rise by a process of polymerisation to some form of sugar.

A modification o. this hypothesis has been advanced, which suggests that the preliminary decomposition of the carbon dioxicle and the water may not take place, but that by a rather less violent reaction between them the formaldehyde may be formed and the oxygen liberated.

Erlenmeyer has suggested a somewhat different course of reaction, yielding substantially the same results. He thinks it possible that the first interaction of carbon dioxide and water leads to the formation of formic acid and hydrogen peroxide, and that these subsequently interact with each other, yielding formaldehyde and water and giving off oxygen.

Many years after the views of Baeyer appeared, a hypothesis of a different nature was proposed by Crato. $\mathrm{He}$ suggests that the carbon dioxide after absorption becomes ortho-carbonic acid, and that this remains in solution in the cell sap. This acid has the structure of a closed benzene ring in which six molecules are linked together. This becomes decomposed, liberating six molecules of water and six molecules of oxygen, 
and forming a hexavalent phenol which subsequently undergoes a molecular rearrangement and becomes glucose.

Yet another suggestion was made by Bach in 1893. He points out that when sulphurous acid is exposed to light it becomes transformed to sulphuric acid, sulphur and water being split off, and he argues that a process analogous with this may take place in a leaf. The carbon dioxide uniting with water would form carbonic acid, and this might then split up in the same way as the sulphurous acid. The carbon and the water thus split off are on this hypothesis not set free separately, but in combination as formaldehyde. The higher carbon acid, to which Bach ascribes the formula $\mathrm{H}_{2} \mathrm{CO}_{4}$, splits up into carlon dioxide and hydrogen peroxide, and the latter is decon:posed into water and free oxygen.

Lieben has still more recently put forward the view that formic acid and not formaldehyde is formed by the first decompositions. He has found that leaves of grasses and variors trees yield formic acid among other products when mixed with their own weight of water containing a trace of sulphuric acid and distilled with steam. Moreover, when carbon dioxide is acted upon by nascent hydrogen the only product is formic acid.

These speculations afford many points which might be well made the starting places of research. The views of Bacyer have met with most acceptance, though but little success has attended the few efforts that have been made to establish them by experiment.

They involve several definite stages of action, of which the most iniportant seem the production of carbon monoxide and hydrogen, the formation of formaldehyde and the construction of a sugar. The last 1 wo questions arise also in connection with the hypothesis of Bach.

If we examine the work that has been published bearing on the probability of the formation of carbon monoxide in the plant we find little that is satisfactory. The statements that have been made are opposed to the idea that carbon monoxide is of value in nutrition ; it is said that when supplied to a plant instead of carbon dioxide it does not lead to the formation of carbohydrates. It is further advanced that this gas is of a very deleterious nature, and if formed would result in the speedy death of the protoplasm of the cell in which it originates. This idea is, of course, specious ; but it does not appear to be well founded. The deadly character of carbon monoxide when in. haled by a human being depends upon a peculiar interference which it causes with the oxygen-carrying power of the red blosd corpuscles. The pigment hremoglobin to which these little bodies owe their usefulness forms a loose chemical com bination with oxygen, the compound being formed in the blood vessels of the lungs and being decomposed with the liberation of the oxygen in those of the tissues of the body. It is evident, therefore, that the value of the corpuscles as oxygen-carriers depends upon their haemoglobin. When this pigment is exposed to carbon monoxide it combines with it in the same way as it does with oxygen, forming, however, a more stable compound. The affinity for this gas which the pigment manifests is very considerable. Hence the poisonous nature of carbon monoxide. It is easily seen that the latter is a poison because it throws out of gear and temporarily paralyses a most essential part of the mechanism of respiration, effectually preventing oxygen from reaching the tissues of the body. There is no evidence here that it exerts even a deleterious influence upon the living sub. stance itself. The only poisonous effect it would be abte to exert on the plant would necessarily be of the latter character, for there is no oxygen-carrying mechanism that could be interfered with. We cannot lay any stress, therefore, on the ob. jection to Baeyer's view, based upon the action of carbon mon. oxide upon the human organism.

Another possibility may, however, be mentioned. As we shall see later, there are certain resemblances between hamoglobin and chlorophyll, the vegetable pigment concerned in photosynthesis. May not carbon monoxide enter into some relationship with the latter, and thereby indirectly hinder its activity? Of that, however, there is no trustworthy evidence, the facts known to us rather pointing in the opposite direction.

The idea of the poisonous nature of this gas may easily be subjected to experimental examination. It would appear easy to expose a plant to an artificial atmosphere made up to different partial pressures of carbon monoxide, to expose it in such atmo. spheres to various conditions of warmth and illumination and to note the effect produced. It would seem possible to examine a great variety of plants in that way, to try both aërial and aquatic forms, and indeed to test the matter exhaustively. It must be borne in mind, however, that the solubility of carbon monoxide in water is extremely small, and that there may be a great difficulty in getting it brought within the scope of the influence of the living substance on that account. It must necessarily be in solution in the cell sap before it can affect the activity of the chloroplast. Even the relations of solubility are not, however, outside the range of experiment, and it may be that the slightly acid celi sap has not the same peculiarities as water as a solvent for the gas.

It is important, again, to take into account in such work the factor of sunlight, on which the power of photosynthesis de. pends. Should carbon monoxide prove capable of serving as a basis for the formation of carbohydrates, the question would arise, Is the activity of the chlorophyll in sunlight confined to the preliminary formation of carbon monoxide from the dioxide, or is the energy derived from the light brought to bear upon the subsequent constructive processes? We have little or no accurate information as to the way in which the energy is utilised after absorption by the chlorophyll.

This opens up a very important but very difficult line of work, which bring: home to us the intimate dependence of vegetable physiology upon physics. The absorption of energy from without, in the form of the radiant energy of the solar rays, is certainly a fact, and to a certain extent we can picture to ourselves the way in which it is secured. The spectrum of chlorophyll shows us a number of absorption bands whose position corresponds with the position in the spectrum of the places where oxygen is liberated in photosynthesis. But the transformation and applications of energy in the body of the regetable organism need much closer examination. The intimate relationship between the different manifestations or forms of energy and the ways in which they can be transformed into one another have been very minutely scrutinised in recent times. What then should hinder us from learning something much more definite than we at present know about these translormations in the róle of vegetable life? The electrical phenomena connected with the movements of the leaves of the Venus's fly-trap (Dionaea muscipula) have been examined with considerable completeness hy Burdon Sanderson, and we have learned that the vegetable and animal organisms show considerable similarities in this respect. Recently, again, Bose has made important contributions to the subject of the electrical responses to stimu. lation that can be observed under particular conditions. A promising beginning has thus been made, but only a beginning. The electrical condition of the normal plant under different conditions of rest and activity has still to be investigated. If we return to the subject of photosynthesis and the work done by the chloroplast, may we not hope to discover something about the transformation and utilisation of the radiant energy associaled somehow with this structure? Considering the relations between the manifestations of energy which we appreciate respectively as light and electricity, it does not stem wildly im. probable to imagine that the energy absorbed as the former may lead to a possible electrolysis of carbonic acid under the influence of the chloroplast, with the formation of carbon monoxide and oxygen. Pfeffer has suggested that perhaps the decom position of the gas is not due to the light rays at all, and that they may exercise only a stimulating influence upon the chloroplast, the energy concerned being derived from heat rays directly absorbed, or heat vibrations derived from the more rapidly vibrating light rays. In this case is the decomposition brought about directly by the heat vibrations, or have we a transmutation into some other form of energy? The whole subject seems at all events a promising subject for inquiry.

Another problem connected with the action of chlorophyll is associated with the absorption of radiant energy by the different regions of the spectrum. Bands of considerable inten. sity are noticeable in the blue and violet, though the deepest absorption takes place in the red. Yet Engelmann's classic bacterium method shows us that very little evolution of oxygen takes place in the position of these bands in the blue and violet. The fact that absorption of radiant energy and photosynthetic activity show no quantitative relationship is of course not new, but the reason remains still to be discovered. Van Tieghem has suggested an explanation which recalls to us the hypothesis advanced by Pfeffer, just alluded to. This explanation is that there are two factors concerned in the action of chlorophyll, the elective absorption of light, shown by the occurrence of the

NO. 1719 , VOL. 66] 
absorption bands in the spectrum, and the calorific energy of the absorbed radiations. The failure of the rays of the blue and violet to effect photosynthesis, in spite of their absorption, would on this view be attributable to their possessing but little calorific energy. The latter is associated much more strongly with the deep band in the red, which is the seat of the maximum evolu. tion of oxygen when the spectrum is thrown upon a collection of active chloroplasts. The heating rays alone are ineffectual, as shown by the fact that there is no liberation of oxygen in the region of the infra-red, due no doubt to the fact that chlorophyll does not absorb these rays.

Timiriazeff, in his classical researches on the liberation of oxygen by the leaves of the bamboo when exposed in tubes of small calibre to a large spectrum, found that the amount of carbon dioxide decomposed by leaves is proportional to the distribution of effective calorific energy in the spectrum.

Van 'Tieghem's hypothesis that this is a matter of calorific energy may prove to be erroneous, and yet his views may rest on some sound basis. It may be a matter in which electrical rather than calorific energy may be concerned.

Returning now to the chemical steps demanded by Baeyer's hypothesis, there are certain considerations which may be urged in favour of the view that carbon monoxide really occurs in photosynthesis. It has been ascertained by Norman Collie that when a mixture of gases containing a large proportion of carbon dioxide is exposed at low pressures in a vacuum tube to the action of an electric discharge from an induction coil, there is a very large formation of the monoxide, together with oxygen, in some cases as much as 70 per cent. of the gas undergoing decomposition.

Appealing to the experience of various observers, there seems on the whole to be a balance of evidence in favour of the power of plants to live and prosper in an atmosphere containing a very considerable percentage of carbon monoxide.

The question of the possibility of the latter replacing the dioxide, as the theory appears to require, is complicated very sericusly by the differences of solubility between them. Carbon dioxide dissolves very readily in water and in cell sap; carbon monoxide is almost insoluble in either. As the amount of a gas taken up by a solvent depends, not only on its solubility, but upon its partial pressure, it is very evident that we canno compare the two gases by admitting the same quantity of both to plants under simultaneous comparison. It is only necessary to supply the dioxide in the proportion of four parts in 10,000 but the almost insoluble nature of the monoxide makes it inevitable that from 2 to 5 per cent. shall be experimented with. The same question of solubility makes it almost out of the question to experiment with an aquatic plant.

It would be of considerable interest from this point of view also to inquire whether if carbon monoxide is liberated at the outset of the photosynthetic processes its combination with other groupings can take place apart from the action of chlorophyll. If so, the fungi should be capable of carbohydrate construction if supplied under proper conditions with the monoxide and with hydrogen. The proper conditions, however, might be extremely difficult to establish.

The next stage in the constructive process affords still ample room for investigation. The presence of formaldehyde is not the hypothesis of Baeyer alone, but is demanded according to Bach's views, though the stages of its hypothetical construction are not the same. We have therefore to ask whether form. aldehyde can be detected in plants, and if so whether the conditions under which it may exist admit of its being con sidered an up.grade product in photosynthesis. Objections to the theory of its formation may be advanced, based upon its un doubtedly poisonous nature. Of all the antiseptics now available to the bacteriologists it is perhaps the most potent, even traces being fatal to the form of vegetable protoplasm which is found in bacteria. We may argue that it must be equally deleterious in the cell containing chlorophyll and to the chloroplas itself, as we have no reason to suppose that any difference in vitality exists between the protoplasm of different plants. A first sight this appears an almost insuperable difficulty in the way of the theory. Formaldehyde has, however, the properties of aldehydes in general, one of which is the power of condensa tion or polymerisation. It passes with extreme readiness into a much more inert form, para-formaldehyde, a body in which three molecules of the formaldehyde are grouped together. I is therefore possible that it may be prevented from exercising its deleterious properties by a transformation at once into this comparatively harmless modification. This will slowly decom. pose under proper conditions, giving off the free aldehyde.

Pollacci has stated that it is possible to extract formaldehyde from leaves. In his experiments he took such as had been exposed to light for a very considerable period and then macerated them in water. After a sufficient extraction he distilied the leaves, together with the water in which they had been steeped. The first portions of the distillate yielded reactions indicative of the presence of formaldehyde. His experiments do not enable us to say that free formaldehyde was there, for the more stable para-form would be likely to decompose during the distillation, so that the reactions would be explained without demanding the presence of the free aldehyde in the leaves.

But little success has attended hitherto the attempt to show that formaldehyde, in the presence of chlorophyll, or preferably, we may say, of chloroplasts, can give rise to carbohydrates. We have nothing more satisfactory than Bokorny's experiments, in which, after failing to set up photosynthesis in a filament of Spirogyra fed with formaldehyde, he succeeded when he supplied the alga with its compound with sodium-hydrogen-sulphite. Experiments on a more comprehensive scale, conducted on a variety of plants of different habits, are needed before we can regard the process as satisfactorily established.

We have further to pursue the problem by an inquiry as to the nature of the sugar first formed. Certain considerations lead to the view that it is probable that a sugar of the aldose type must be accompanied in the plant by a ketose. The hypothesis as stated by Baeyer, and so far accepted until quite recently, took no account of the latter. The aldose grape sugar was the one always suggested, and from this all others met with have been held to be constructed. The first appearance of a ketose, levulose, or fruit sugar, has been associated with the hydrolytic decomposition of cane sugar, itself constructed presumably from the grape sugar. I fear sufficient attention has not been paid to probability or to the normal course of chenical action in framing our hypotheses, for it is rather difficult to see how some of the transformations somewhat dogmatically affirmed can possibly take place. I may refer in passing to the statement that in the digestion of fat or oil during germination part of it is converted into starch or sugar.

But to rtturn to the construction of sugar. The condensation of formaldehyde, which can be brought about by the action of basic lead carbenate, leads to the formation of several sugars, each yielding its characteristic osazone. How far the condensation in the plant follow's this is still uncertain. It is quite possible that stages intervene between formaldehyde and sugar of any kind. It has been suggested that formaldehyde in the presence of water may under the conditions obtaining in the leaf give rise to glycolaldehyde, a body which forms sugar very readily indeed. The formation of suyar direclly from formaldehyde is a much longer process and is attended with greater difficulty.

I may call your attention here to the vicws of Brown and Morris traversing the theory of the primary carbohydrate being grape sugar. In their classical paper on the chemistry and physiology of foliage leaves, they have adduced strong evidence, based upon analyses of the sugar-content of leaves of Tropaeolum majus, that in this plant at any rate the first sugar to be formed is cane sugar. Whether or no this is the case in plants generally cannot at present be said, though it appears from many considerations probable.

The part played by chlorophyll in photosynthesis has already been touched upon. Remarkably little is known about chlorophyll itself. It has so far been found impossible to extract it from the chloroplast without causing its decomposition, and hence our ideas of its constitution, such as they are, are based upon the examination of something differing in some not well-ascertained particulars from the pigment itself. A remarkable relationship is known to exist between the latter and iron, for unless this metal is supplied to a plant its chloroplasts do not become green. But the condition of the iron in the plant is uncertain; it seems probable that it does not enter into the molecule of the pigment at all. A remarkable series of resemblances between derivatives of chlorophyll and derivatives of hæmatin, the colouring matter of haemoglobin, has been brought to light by the researches of Schunck and Marchlewski, which is very suggestive. The same leaning towards iron is found in the two pigments, but in the case of hrematin our knowledge is further advanced than in that of chlorophyll. The iron is known to be part of its molecule. It can by appropriate treatment be

NO. 1719 , vol. 66] 
removed, and a body known as haematoporphyrin is then formed, which presents a most striking similarity to a derivative of chlorophyll which has been named phylloporphyrin. The two pigments are almost identical in their percentage composi. tion, the hæmatoporphyrin containing a little more oxygen than the other. Both seem to be derivatives of pyrrul. The most striking similarity between them is their absorption spectra, their ethereal solutions both showing nine bands of identical width and depth, those of hematoporphyrin being a little more towards the red end of the spectrum. Their solutions in alcohol and ether show the same colour and the same fluorescence. Though they differ in certain other respects, notably the facility with which they form crystals, it is impossible to deny that a close relationship seems probable. If this is established, we may by analogy perhaps learn something about the part played by iron in the action of the chloroplast, which so far has proved as obscure as the relation of the metal to the pigment. It is very suggestive to recall the resemblances between the two pigments, the one playing so prominent a part in animal, the other in vegetable life. Both are associated with a stroma of proteid, or possibly protoplasmic, nature, in which a sulution of the pigment is retained, apparently after the fashion of a sponge. Both are concerned in metabolic processes in which gaseous interchanges play a prominent part. Both are in some way dependent on the presence of iron for their individuality, even if iron is not actually present in the molecule of both. The iron being removed, the derivatives which are found are almost identical. Further researches may throw a light on this curious relationship, perhaps showing that chlorophyll may enter into a combination with carbon dioxide as himatin does with oxygen. Such a combination might well be the precursor of the decomposition of the carbon dioxide which has been already spoken of.

We meet with another pigment in many plants the physiological significance of which has in recent years begun to attract some attention. This is the red colouring matter, anthocyan, apparently related to the tannins, which is developed especially in the young leaves of shade-loving plants when they become exposed to illumination exceeding the intensity which they normally encounter. The formation of this pigment is greatest in tropical plants, where it is found usually in the epidermis of the young leaves, though in some cases it extends to the mesophyll as well. The pigment seems in some way to be supplementary to chlorophyll, for its absorption spectrum shows that it allows all the rays useful in photosynthesis to pass through it. It is unlikely that it lakes any share in photosynthesis. Several theories have been advanced to explain its presence; it may be simply to protect the delicate cells from the destructive action of too intense light, or to avert the evil of overheating from the solar rays. It has been suggested that certain rays hinder the translocation of starch, and that the pigment shields the cells from the incidence of such rays. Again, the view has been advanced that the red colour is important in accelerating the development of diastase from its anteceden zymogen, which has been found to take place under the influence of the rays of a certain region of the spectrum. While all these views have been advanced, however, there is little positive information bearing upon either the formation or the function of the pigment.

$V$ ery little progress has been made with the problem of the construction of proteid matter in the plant, which still confronts us. The uuestion of its relation to the mechanism of phdto synthesis has received some attention without leading to any satisfactory conclusion. Winogradski's success in cultivating the nitrate bacteria upon purely inorganic matter reveals an unexpected constructive power in some forms of vegetable protoplasm. The question of the energy made use of in proteid construction is in an equally unsatisfactory condition. Laurent, Marchal and Carpiaux have stated that the rays of the violet and ultra-violet region of the spectrum are absorbed and devoted principally to the construction of nitrogen compounds from the nitrates, or the compounds of ammonia, which are absorbed by the plant, while the intervention of the chlorophyll apparatus is unnecessary for this purpose. The experiments which they give in considerable detail upon this absorption carry much weigh and appear conclusive. Unfortunately, other observers have failed to confirm them, so that at present the matter must be left open.

Among the problems connected with the nutrition of the plant, the part played by alcohol has recently come into promin- ence. Alcohol was originally associated only with the lower fungi, and especially with the yeast plant. Biological problems of grave importance arose in connection with the Saccharomyces, apart from what seemed at first the larger question, viz. the nature of fermentation. A prolonged study of the latter phenomenon led Pasteur to the view that alcoholic fermentation is only the expression of the partial asphyxiation of the yeast, and its efforts to obtain oxygen by the decomposition of the sugar. It is hardly necessary here to remind you of the con. troversies that centred about the question of fermentation and the theories held and abandoned as to its cause. The biological phenomena have, however, a claim now upon our attention in the light of some very remarkable researches that are calling for our attention and criticism to-day. Pasteur's explanation of the behaviour of the yeast was, as we have seen, such as to connect it with the respiration of the plant. When oxyge. was withheld from active yeast, 6o-8o parts of sugar disappeared for one part of yeast formed. When oxygen was present, not more than ten parts of sugar were decomposed for the same amount of yeast production. Undoubtedly the stimulus of asphyxiation materially stimulated the yeast metabolism.

But certain observations did not agree with Pasteur's explanation. An energetic fermentation takes place in the presence of oxygen, the plant multiplies extremely quickly, and its metaholism appears very active. Schuitzenberger argued against Pasteur's explanation with some force, emphasising these points of disagreement between his hypothesis and the facts, and claimed that the matter rather concerned nutrition than respiration. He based his view on experiments carried out to ascertain how respiration was affected under changed conditions.

The results he obtained were briefly the following :-

(I) In a watery liquid without sugar, but containing oxygen in solution, the quantity of oxygen absorbed in unit time by a gramme of yeast is constant, whatever proportion of oxygen is present.

(2) In a saccharine liquid containing albuminous matter as well as sugar, and with oxygen in solution, the same result is obtained, except that the quantity absorbed in unit time is greater.

(3) In two digestions carried on side by side for some time, one being supplied continuously with oxygen and the other deprived of it, the former produced most alcohol.

If the decomposition of the sugar had been the result of the respiratory activity of the yeast cells at the expense of the combined oxygen of the sugar, it would seem that fermentation should either not have taken place at all in the presence of free oxygen or that it should have been much less than in the other case, whereas the reverse is what is found. Hence Schuitzenberger advocated the view that the sugar is alimentary and not respiratory.

Certain facts more recently discovered support strongly the vicw that the nutrition of the yeast is the chief object of the process normally, though we cannot deny that when partial asphyxiation sets in, fermentation is resorted to by the plant in its difficulty, that it may obtain the energy normally supplied by the respiratory processes. The mode of decomposition of the sugar, however, the formation of alcohol and carbon dioxide, raises a question as $t 0$ the exact form in which the nutritive material is supplied to the protoplasm.

Of these more recent discoveries, the work of Devaux on the trunks of trees may be mentioned first, as it seems to point to a similar problem to the one connected with yeast. Devaux examined the composition of the air in the interior of woody stems growing under normal conditions, and found that the proportion of oxygen it contains often sinks as low as 10 per cent., while in a few cases, in the most internal part of the tree, he found this gas to be entirely absent. The disappearance of oxygen becomes easier with every increase of temperature. The partial asphyxiation is attended by the formation of alcohol in the struggling tissue, the spirit being detected by cutting up the branches of the trees and distilling them with a large excess of water. Ilevaux's experiments were made upon a considerable variety of trees, among which may be noted Castanea vulsaris, Pyrus domestica, Alnus.glutinosa, Ulmus campestris, Sambucus nigra and Ficus Carica.

Similar results have been obtained by Mazé in some researches on seeds. When a number of these are submerged in water, micro-organisms being properly guarded against, they do not readily germinate, but their weight nevertheless somewhat rapidly diminishes. In some of Mazé's experiments with peas, he

No. I7 I9, voL. 66] 
ascertained that this diminution was attended by a considerable formation of alcohol. Three parcels of forty peas were examined, weighing respectively 10, 17 and 27 grammes, and the experiments lasted six, twelve and twenty-seven days. He found the proportion of alcohol to the original weight of the peas was $2 \cdot 34,4.63$ and 6.56 per cent. As the peas were sub. merged, and so kept out of contact with air, it seems possible to suppose we have here again an effect of asphyxiation. Other experiments, however, make this view unsatisfactory. II germinated twenty peas at $22^{\circ} \mathrm{C}$. for seven days under norma conditions, till their axes were about $1 \frac{1}{2}$ inches long. He then covered them with water, in some cases leaving the terminal bud exposed to air. The development of the submerged plants stopped at once, and at the end of five days the liquid contained 130 milligrammes of alcohol. The seedlings whose terminal buds were exposed to the air continued to grow without showing any disturbance. Mazé concludes that the alcohol produced was utilised by them in their growth, and suggests that it is a normal and necessary product of the digestion of carbohydrate material in seeds in course of development.

$\mathrm{He}$ goes on to show that alcohol can be demonstrated to be present in plantlets that have germinated for forty-eight hours at $23^{\circ} \mathrm{C}$. under normal conditions.

Another worker of great eminence who has found similar conditions to exist in normal vegetation is Berthelot. IIe put blades of wheat and leaves of the hazel in fiasks, displaced the ai by hydrogen, and distilled. In the case of the wheat he heated the flask to $94^{\circ} \mathrm{C}$., in that of hazel he conducted the distillation by passing steam through the flask. In both he found the distillate contained alcohol. The quantity was not large, but still measurable; from ro kilos. of leaves he obtained 10 grammes of alcohol.

Mazé claims to have found alcohol under normal conditions in the stems and leaves of the vine.

Mazé finds, further, that the weight of a seedling of maize approximates at any moment during the early stages of germination to half that lost by the reserve store in the endosperm.

From his experiments, and those of the other authors alluded to, he concludes that alcohol is formed in the living cells of seeds at the expense of grape sugar by virtue of a normal diastasic process, which makes them approach yeast cells more closely than has been suggested by any of the experiments hitherto published. We may inquire further how far the evidence points to the probability that the molecule of sugar is split up in that way into alcohol and carbon dioxide, and that the alcohol is the nutritive part of the sugar molecule. Certainly Mazé's experiments on the submerged seeds with the plumule exposed above the water are not inconsistent with that view. Duclaux has spoken more definitely still on this point, and has said that the alcohol formed becomes a true reserve material to be used for nutriment.

We have, however, further evidence that to some plants, at all events, alcohol is a food. Laborde has published some researches conducted upon a fungus, Eurotiopsis Gryoni, which point unmistakably to this conclusion. He cultivated it in a solution containing only the mineral constituents of Rawlin's fuid and a certain percentage of alcohol, usually from 4 to 5 per cent. The plant grew well, furming little circular patches of mycelium, which enlarged radially as the growth progressed. The mycelium bacame very dense in the centre of the patches, and the fungus evidently thrived well. As it grew the alcohol slowly disappeared, the rate b sing absut equal to that of sugar in a similar culture in which this subitance replaced the alcohol. The mycelium in some experiments was cultivated quite from the spores. Eurotiopsis is a fungus which has the power of setting up alcoholic fermentation in saccharine solutions. When cultivated in these, alcohol is accordingly produced, and subsequently used, but the growth of the mould is not so easy under these conditions as when the alcohol is sup. plied to it at the outset.

Duclaux has shown that in the case of another fungus, the well-known Aspergillus nigrer, though alcohol kills it while it is in course of germination from the spore, it can utilise for nutrition 6.8 per cent. when it becomes adult, continuing to grow, and putting out aërial hypha. Eurotiog sis is more pronounced in its liking for alcohol, for it thrives in a mixture containing 10 per cent. ; even if submerged entirely it continues to grow and flourish in an 8 per cent. solution.

The peculiarity relates only to ethyl alcohol; methyl aicohol will serve as a nutritive medium for only a little time, sufficient only for the commencing development of the spores into a mycelium and disappearing very slowly from the culture fluid. The higher alcohols, propyl, butyl and amyl, not only give no nourishment, but are poisonous to spores. A very small trace of any of them can be used by the adult mould.

Laborde claims to have established as the result of his investigations that Eurotiopsis normally makez alcohol from the sugar to nourish itself with it, just as yeast makes invert sugar from cane sugar because it is the nutritive material it likes best. The enzyme zymase is present in the fungus and plays the part of an alimentary enzyme. Its consumption lasts twice as long as that of a corresponding weight of glucose; it can serve twice as long for the nutrition of the same weight of plant.

These remarkable results lead us to the consideration of the mode in which the carbohydrates, and particularly the sugars, are assimilated by the plant. We have held the view that the sugar molecule is capable of entering with little if any alteration into that of protoplasm. We have found no direct evidence bearing upon its fate. It is possible to detect sugar in the axis of a plant till quite near its growing point. Then the reaction ceases to be obtainable, and we know that assimilation is taking place. But we have still to investigate the steps, no very easy problem to undertake. May it possibly be that it is the alcohol moiety of the sugar which the protoplasm takes up, part of the carbon dioxide evolved by the growing organ being an expression, not of respiration, but of a fermentation preliminary to assimilation?

But I feel I have dealt at sufficient length with this question. I pass, therefore, to consider briefly another nutrition problem of a rather different kind. The germination of seeds is a question that might be thought to have been fairly settled by the investigations of the latter half of the last century. We have come to the conception of the seed as fundamentally a young embryo lying quiescent within its testa, and provided with a store of nourishment deposited either within its own substance or lying round it in the tissues vaguely named endosperm or perisperm. The nourishment has been held to be practically ready for its use, needing only a certain amount of enzyme action to be applied to it to convert the food store from the reserve to the nutritive condition. We have recognised here starch, proteids and glucosides, and have ascertained that the embryo can furnish the appropriate enzymes for their digestion. Each reserve store has apparently been quite in tependent of the rest, and the embryo has had control of the whole.

Certain considerations, however, lead us to the view that for albuminous seeds at any rate this mode of looking at the matter is no longer satisfactory. We may first ask how far the embryo is the controlling factor in the digestion. Putting the matter in another form, is the influence of the parent plant lost when a stable store of food has been provided for the offipring, and does it leave its utilisation entirely to the latter? Is the gametophyte prothallus merely to become a dead or inactive structure as soon as it has developed its young sporophyte, or may its influence extend for the longer period of germination? There are many reasons for thinkhig this is the case. Indeed, the view has been put forward by some ouservers at intervals for some years. Gris claimed to have shown it in I864; but it was opposed by Sachs; who said that the enzymes which cause decompositions in the reserve materials are always formed in the young plant or embryo and are excreted by the latter into the endosperm. Some careful experiments on the point were conducted by Van Tieghem and were published by him in 1877 . His work was carried out on the seeds of the castor-oil plant. He deprived the seeds of their embryos and exposed them for some weeks on damp moss to a temperature of $25 \cdots 30^{\circ} \mathrm{C}$. After several days of this exposure, he found the isolated endosperms were growing considerably; and at the end of a month they had doubled their dimensions: In the interior of the cells he found the aleurone grains to be gradually dissolving, and the oily matter to be diminishing; though slowly. The dissolution extended throughout the mass of the endosperm, and was not especially prominent in the side that had been nearest to the cotyledons. He noted, too, that though starch did not normally appear in the germinating endosperm, under the condition of non-removal of the products of the decomposition, it did appear in the cells in the form of small grains, though not till after several days had elapsed. Van Tieghem also observed that the progress of the decomposi. tions could be arrested and the endosperms made to reassume a quiescent condition, and that then the aleurone grains again became formed, though in less quantity than before.

NO. 17 I9. VOL. 66] 
In some experiments on Ricinus which I carried out in 1889 , I found much the same sequence of events as Van Tieghem had described. The endosperm unquestionably became the seat of a renewed metabolism, in the course of which many interactions between the various reserve materials became noticeable. It was remarkable that the activity of this metabolism was much more pronounced when the embryo or parts of it were left in contact with the endosperms.

An observation of a sinilar character has been made by Haberlandt and by Brown and Morris in the case of the seeds of grasses. The conversion of the reserve cellulose of barley grains has been shown by these observers to be the result of the action of an enzyme cytase, which is secreted largely by the so-called aleurone layer, which is found surrounding the endosperm, immediately underneath the testa.

Recently my own work has been bearing on this question, particularly as regards the behaviour of the seeds of Ricinus during germination. The reserves of this seed are mainly composed of oil and aleurone grains, hardly a trace of carbohydrates being present. At the onset of germination there is a remarkable appearance of both cane sugar and glucose, which increase as the oil diminishes. The old view advanced to explain this fact has been the transformation of the oil directly into the sugars or one of them, a theory which it was difficult to teconcile with the chemical possibilities of oil. I have found that side by side with the appearance of the sugar we have also the formation of a considerable quantity of lecithin, a fatty body containing nitrogen and phosphorus. The seed contains a comparatively large amount of phosphorus in the form of the well-known globoids of the aleurone grain, a double phosphate of calcium and magnesium. The occurrence of this body points to a considerable interaction of various substances existing in the seeds, the phosphorus apparently coming from the globoids and the nitrogen from the proteids. Instead, therefore, of the fat being transformed into sugar, it seems certain that a very considerable metabolism is set up, in which the very constituents of the endosperm interact very freely together. I am informed by $\mathrm{Mr}$. Biffin, who has investigated the histological changes accompanying the germination, that the protoplasm of the endosperm cells appears to increase in amount very greatiy during the early stages. The observations suggest a very vigorous resumption of metabolic activity by the cells of the endosperm, in the course of which the various reserves are brought into relation with the living substance of the cells and a number of new products are formed to minister to the nutrition of the growing embryo. The formation of the sugars may more probably be referred to the renewed activity of the protoplasm of the parent gametophyte than to a direct transformation of the fat under the influence of the embryo. liurther researches upon a large variety of seeds appear necessary to give us a true idea of the chemical processes of germination. What now appears probable in the case of fatty seeds may prove to be true also in the case of those which have other varieties of reserve material.

I have already alluded to the problems concerning the electrical phenomena presented by the plant at rest and during activity. Very little work has so far been done in this direction, and our knowledge of the subject is materially less than that concerning similar phenomena in muscle and nerve. Still a beginning has been made, and we have observations on record due to Waller and to Bose which are of the greatest interest, not only because they show a great correspondence in behaviour between animal and vegetable structures, but on account of their possible importance in determining the character of many of the metabolic processes and the forces at work in the tissues.

Some very striking results were only a few months ago published by Bose on the electric response in ordinary plants to mechanical stimulation. He arranged a piece of vegetable sub. stance, such as the petiole of the horse-chestnut, or the rbot of a carrot or a radish, so that it was connected with a galvanometer by two non-polarisable electrodes. The uninjured tissue gave little or no evidence of the existence of electrical currents but if a small area of its surface was killed by a burn or the application of a few drops of strong potash, a current was observed to flow in the stalk from the injured to the uninjured area, just as is the case in animal tissue. The potential difference in a typical experiment amounted to 0.12 volt. The tissue was then stimulated, either by tapping or by a torsion through a certain angle, and at once a negative variation.or current of action was indicated, the potential difference being decreased by 0.026 volt. Very soon after the cessation of the stimults, the tissue recovered and the current of rest flowed as before. Bose's investigations extended considerably beyond this point, and established a very close similarity in behaviour between the vegetable substance and the nerves of animals. Summation effects were obgerved, and fatigue effects demonstrated, while it was definitely shown that the responses were physiological. They ceased entirely as soon as the piece of tissue was killed by heating.

This remarkable demonstration of similar electrical properties to those pussessed by nerve strengthens very greatly the view of the conduction of stimuli in the plant by means of the protoplasmic threads which have been demonstrated by Gardiner and others to exist throughout the plant, uniting cell to cell into one coherent whole.

Much remains to be done in this field; indeed, not more than a beginning has been made. The electrical accompaniments to response to stimuli have been investigated by Burdon Sanderson in the case of Dionaea, but many other instances are still awaiting examination. The peculiar phenomena of electrotonus and their relation to stimulus have so far oniy been observed in animals.

These observations strengthen considerably the view of the identical nature of animal and regetable protoplasm which has in recent years come into prominence, and which is receiving. more and more support in all directions.

These electrical currents, following mechanical action, which no doubt is accompanied by chemical change, make us ask whether electrical phenomena do not in all probability accompany the slow chemical actions which we call metabolism. The view that electrical energy is concerned in the processes of photosynthesis, suggested in an earlier part of this Address, is certainly not weakened by a consideration of these phenomena.

The probability of the transmission of stimuli through vegetable tissue along the protoplasmic threads, extending from cell to cell, has been supported during the last year or two by some remarkable observations claimed to have been made by Nemec on certain roots and other organs. He says he has succeeded in demonstrating a continuous fibrillar structure in the protoplasm of the cells, fibrils passing along it in a longitudinal direction and apparently connecting the protoplasm of a longitudinal series of cells into a conducting chain. These conducting strands extend between the sensitive region-e.g. the tip of the root-and the region which is growing, and which is caused by the stimulus to curve. Nemec say's that these conducting strands can be made evident by the use of appropriate staining reagents. They vary in number and position, but appear to be confined to sensitive and motile organs.

It is clear that the matter cannot rest where it is. The statements made by Nemec call for investigation by both histological and physiological methods. It is possible that appropriate reagents may lead to the recognition of structure in what has been hitherto regarded as undifferentiated protoplasm.

Before concluding this Address I may call attention to the vast field opening up in connection with the pathology of plants. The work done by our predecessors has been more largely work on the morphological peculiarities of various fungi than upon the physiological changes which constitute pathology, properly so called. It is only recently that attention has been given to the broad questions of disease in plants. Even now, however, certain advances have been made, and the direction of research is taking shape. In the science of pathology, little in recent years has been so fascinating as the question of immunity against the attacks of certain diseases, either hereditary or acquired. It has been bound up with the very large question of toxins and their attenuation, their opposites, the antitoxins and matters of a similar nature.

Great results have been obtained in human pathology, with which it is not for me to deal. I mention them here because we are face to face with the possibility of treating some of the diseases of plants in a similar way, and perhaps on the threshold of very far-reaching discoveries.

I may call attention to the discoveries of Ray and of Beauverie upon the general question of plant infection and especially upon a disease set up by a fungus known as Botrytis cinerea, which attacks grapes, begonias and other plants. The fungus exists in three forms, one of which is a harmless saprophyte, another a destructive parasite and a third intermediate between the two. The first is a very common fungus, developing on decaying plants and bearing ordinary gonidia or spores. The second is completely filamentous and bears no reproductive

$$
\text { No. } 1719 \text {, vOL. 66] }
$$


organs. It is produced when the air is heavily charged with moisture and the temperature high, conditions of common occurrence in forcing houses. The third is an attenuated form intermediate between the other two. It bears gonidia like those of the first, and in addition others which germinate without falling off the parent plant and elongate into long threads. Many plants can bear the invasion of this plant without suffering greatly, though it cannot be called harmless. It occurs chiefly when a high temperature is associated with a considerable amount of moisture in the air.

It is not difficult to cultivate this attenuated form of the Botrytis in sterilised soil. Beauverie describes one experiment made with it which is very striking. Damp earth was sterilised in a Petri dish of large surface, sown with spores of the Botrytis and kept at a temperature of about $16^{\circ} \mathrm{C}$. After three days, the surface of the dish was covered with a loose mycelium, which bore numerous gonidiophores. The fungus was allowed to grow for some time under these conditions, and the infected earth was then transferred to fresh pots in which were placed cuttings of begonias. The plants grew well and were not sensibly affected by the presence of the fungus in the substratum or in its surface. Placed subsequently in conditions which were eminently suitable to the development of the parasitic form, they resisted its action perfectly, though control plants which had not been cultivated in the ground infected by the attenuated form were killed very quickly. From their experiments the authors claim to have shown that the form of Botrytis cinerea intermediate between the gonidial and the sterile form can make plants immune to the attacks of the latter.

Researches of a somewhat kindred nature dealing with the infection of particular plants by specific fungi have been communicated recently to this Section by Prof. Marshall Ward in his paper read last year on the Bromes and their brown rust. They brought to light many very important facts connected with the question of adaptive parasitism and immunity. Few questions in vegetable physiology can compare in economic importance with these when we think of their possible develop. ment in relation to agriculture.

I have now somewhat hurriedly surveyed certain parts of the field of vegretable physiology. It has been impossible in an Address like this to do more than indicate what seem to me some of the more important problems awaiting investigation. May we hope that all such work will be vigorously conducted, but that the conclusions reached will be scrutinised with the greatest cart and subjected to repeated examination? Great hindrances to the advance of the science resulted from dogmatic assertions made by eminent men in the past, their personal influence having led to their conclusions, not altogether accurate, being nevertheless almost universaliy accepted. Many years subsequently these conclusions have needed re-examination, the result being the destruction of a whole fabric that had been reared upon this unworthy foundation. I may close, as I began, by an appeal to the younger school of botanists to take some of this work in hand, and by assiduous and critical experiment and observation to contribute to the solution of the problems pres. sing upon us in this field.

\section{SECTION I.}

EDUCATIONAL SCIENCF.

Opening Aduress hy Prof. Hexry E. Armstrong, LL. D., Ph.D., V.P.R.S., PRESIDeNT OF THE SectioN.

THE last meeting of the British Association at Belfast was presided over by Prof. Tyndall, one of whose most memorable discourses was that delivered at Liverpool' in 1870 on "The Scientific Use of the Imagination." In the course of his Address, the P'resident could point out that "science had already to some extent leavened the world," and abundant proof has since been given that he was right in claiming that "it will leaven it more and more." Nevertheless, if we consider the leavening effect which science has had on the public mind, it is impossible to deny that progress is being made in this direction at a woefully slow rate, in no way proportionate to the growth of knowledge or to the recognised usefulness of the many discoveries which are the outcome of scientific investigation. Science is still treated by society as a rich parvenu all the world over, and is at most invited to its feasts, but not incorporated, as it should be, with the domestic life of the people.
Complaint has long been rife that the British are indifferent as a people even to things which are of manifest importance, and which as a nation of business men they might be expected to value. It would certainly seem that we are all too forgetful of Tyndall's warning that "every system which would escape the fate of an organism too rigid to adjust itself to its environment nuust be plastic to the extent that the growth of knowledge demands." As our President said a full quarter of a century ago, "when this truth has been thoroughly taken in, rigidity will be relaxed, things not deemed essential will be dropped, and elements now rejected will be assimilated. The lifting of the life is the essential point, and as long as dogmatism, fanaticism and intolerance are kept out, various modes of lever. age may be employed to raise life to a higher level."

But how are we to become plastic to the extent that the growth of knowledge demands, in order that rigidity may be relaxed, that conservatism may give way to a wise spirit of advance? Probably there is no more important question the nation can ask at the present time ; for that we are wanting in plasticity is proved to demonstration. Does not the sharle of our former President stand before us and solemnly give answer : "By the cultivation and exercise of imaginative power-by the scientific use of the imagination"; for in these days are we not indeed a people "of little faith"? There would seem, in fact, to be clear evidence, if not of destruction, at least of impairment, of imaginative power under modern conditions-that the tendency of education is to kill rather than to develop the very power on which the progress of the world depends. A dearth of imaginative power is strikingly apparent in art, in literature, in music, in science, in public taste generally, the prevailing tendency being to imitate rather than to originate and individualise. Commentators and critics of sorts abound, but these rarely display any catholicity of judgment. Leaders are few and far to seek. The prevailing policy is that of the party in power, and more often than not of a caucus behind it-not the policy which on broad general grounds is the most desirable ; in fact, little attempt is made to discover in any scientific manner what would be the really wise policy to pursue. Nothing could illustrate this better than the state of chaos into which affairs educational are plunged at the present time. Those who dare to differ or offer advice are looked at askance, and always with jealous eyes ; and too often everything is done to block the way of the reformer, not from any base motive, but as a rule from sheer inability to appreciate what is proposed-from sheer lack of imaginative power. Necessarily, as the conditions of civilisation become more complex, the tendency to accept and follow must become greater, and self.satisfaction more and more complete and general; but unless effective means be taken to counteract such a tendency, decay is inevitable.

The phrase "creatures of habit" is familiar to us all ; few will deny that we are seldom otherwise than creatures of habit and that plasticity of mind is a rare attitude. But the growth of knowledge is taking place at such a compound interest rate that a high degree of plasticity is essential if we are to avail ourselves thereof. We were formerly accounted a nation of shopkeepers-of clever shopkeepers-but now the title is passing from us to the Germans and Americans, because they are more alive than we are to the fact that in these days it is necessary both to organise and to be alive to every opportunity. If we would put money in our purse in future, it will be necessary to put imagination into our affairs, so that we may be far more ready to act than we have been of late years.

And not only is knowledge increasing, but our responsibilities are daily becoming heavier and heavier. In the minds of thinking men at the present time, the burden of empire our nation bears is of appalling magnitude; the men who have imaginative power are aghast at the flippant unconsciousness of responsibility manifest in the public at large, and even in the majority of our statesmen and politicians. It is widely felt that a deeper sense of responsibility must be induced among us if we are to maintain our heritage intact-if we are to remain worthy to play the great part for which by an inscrutable ordinance we find ourselves cast at the very commencement of a new century. Nothing is so sure as that if we cannot show our. selves to be worthy we shall not long be allowed to play the part : jealousy confronts us on all sides; and we have learnt that the struggle for existence is Nature's first law, against which philanthropy is powerless so long as it be not universala contiogency which is not even remotely possible. It is little short of remarkable that we should be able to go so far as we

NO. I 7 I9, VOL. 66] 
do in securing the services of able men to conduct our affairs generally ; but we cannot be too mindful of the duty incumbent upon us of developing the store of ability latent in the nation, and above all of maintaining intact our heritage of individuality.

The call to organise the forces of our empire is imperative, but we do not heed it in any proper manner. For many years past we have rarely refused to treat with utmost consideration the representations of those who have dwelt on the importance of our Navy. One of the most highly respected men in the country at the present day is our gifted American cousin, Captain Mahan, on account of the way in which he has exercised his powers of imaginative insight and taught us to understand our achievements at sea, to appreciate the true meaning and value of sea power. We need a Mahan to discuss the larger issues of national defence through education, to teach the nation the true meaning and value of education. The Ship of State is of vastly greater consequence than the mere Navy, and yet those who direct attention to the insufficient character of its armament are scarce listened to ; not the slightest effort is made to secure for it a scientifically adjusted and organically complete machinery for the effective administration and working of all its departments; the drill of its crew is woefully incom. plete; what is worse, there is a terrible absence of organisation and discipline, a terrible absence of willingness, little, if any, desire among those who are charged with its care to cooperate, and the consequences of neglect are not immediately obvious. In war we appreciate the effects suddenly : a long list of killed and wounded brings its meaning home to us at once ; and we know that we must pay the penalty of defeat forthwith. The indemnity exacted can be expressed as a lumpsum. The battle of life is waged in a less obtrusive way, the killed and maimed are not scheduled in any regular manner, and so it escapes our notice that in reality the carnage is awful, that few, if any, escape without severe wounds, that defeat is constant and yet often dealt so silently and imperceptibly that it excites little comment. But we know that vastly more than is done might be done to alleviate if not to prevent suffering, and even to give charm to life where at present there is but pain, if only our efforts could be organised. If we reflect on the bareness of the life lived by the majority, on the debasing conditions under which very many are placed, on the terrible evils consequent on indulgence in drink, surely we must agree with Tyndall that the essential point is to raise life to a higher level, to elevate the general tone of thought, and that it is our duty to consider more seriously than we have done hitherto what use can be made of the forces at our disposal for the purpose.

If we will but picture to ourselves how most of our difficulties, and especially our slow advance, are consequences of lack of imaginative power, or perhaps rather of failure to exert the power which, though latent in most of us, is not sufficiently called into being by practict; if we will but consider how much of our success has been due to the exercise of imaginative power, we may be led to propound a fruitful theory of education, a theoretical basis on which a sound educational struc ture may be reared. It has been well said by Carlyle "that al that man does and brings to pass is the vesture of a thought." In fact, the illustrations which may be given of the value of theoretical conceptions, of imaginative power, are innumerable. Taking recent events, if we consider the success achieved by the late Mr. Rhodes, the narrow-sighted will say he was a practical man; a man who did things and led others to do. Those with broader views recognise that at heart Mr. Rhodes was a theorist, an idealist, a man of imagination, and hence his success. And men such as Lord Roberts and Lord Kitchener, whose immense services to the nation have been so universally admitted of late, are not merely practical soldiers of experience, but men gifted with powers of insight and imagination; men able to apply theory to practice. Some of those who were unsuccessful in the late campaign are currently reported to have gone out to South Africa openly deriding science, and it will be well if the lesson taught by their failure be not disregarded by their colleagues. The importance of the part played by theory in science cannot be exaggerated. We have only to think of the influence exercised by the Newtonian theory of Gravitation, by the Daltonian theory of Atoms, by Faraday's conception of Lines of Force, by the Wave theory in its varied applications, by the Darwinian theory of Evolution; we have only to think of the way in which the reflections of one weak man indited at his study-table in a secluded Kentish village have changed the tone of thought of the civilised world. Such theories are the very foundations of science ; whilst facts are the building stones, theories furnish the design, and it is the interpretation of facts in the light of theory and the considered application of theory to practice that constitute true science. The marvellous development of scientific activity during the past century has been consequent on the establishment of fruitful theories. If teachers generally would pay more attention to theory their teaching would doubtless be more fruitful of results; facts they know in plenty, but they lack training in the considered use of facts: False prophets among us have long taught the narrow doctrine that practice is superior to theory, and we pretend to believe in it. That the belief is founded on misconception may safely be contended, however; the two go together and are in. separable. It is true that we have enjoyed the reputation of being a practical people, and have been accustomed to take no little pride in the circumstances, and to scoff somewhat at theory, but behind our practice in the past there was a large measure of imaginative power, of theoretical insight; in fact, we were successful because we were innately possessed of considerable power of overseeing difficultics, of grasping an issue, of brushing aside unessential details and going straight to the point; in other words, of being practical. We are ceasing to be practical because modern practice is based on a larger measure of theory, and our schools are paying no proper attention to the develop. ment of imaginative power or to giving training in the use of theory as the interpreter of facts; didactic and dogmatic teach. ing are producing the result which infallibly follows in their wake-sterility of intellect.

Mr. Francis Darwin, in his Reminiscences of his father, tells us that "he often said that no one could be a good observer unless he was an active theoriser." And he goes on to say ; "This brings me back to what I said about his instinct for arresting exceptions: it was though he were charged with theorising power ready to flow into any channel on the slightest disturbance, so that no fact, however small, could avoid releasing a stream of theory, and thus the fact became magnified into importanie. In this way it naturally happened that many untenable theories occurred to him ; but fortunately his richness of imagination was equalled by his power of judging and condensing the thoughts that occurred to him. He was just to his theories and did not condemn them unheard; and so it happened that he was willing to test what would seem to most people not at all worth testing.'"

In his Autobiography, Darwin remarks:-" I have steadily endeavoured to keep my mind free so as to give up any hypothesis, however much beloved (and I cannot resist forming one on every subject), as soon as facts are shown to be opposed to it." The italics in these passages are mine.

Our system of education has no proper theoretical basis. Educators have ceased to be practical because they have failed to keep pace with the march of discovery, the theoretical basis underlying their profession having been enlarged so rapidly and to such an extent that it is beyond their power to grasp its problems. The priesthond of the craft are, in fact, possessed by the spirit of narrow parochialism, and upholders of an all too rigid creed, being lineal descendants of a privileged class-" "the knowledge caste," to use Thring's expression-whose functions were far more limited than are those which must now be discharged by teachers if teaching is to be given which will serve as an efficient preparation for life under modern conditions. They enlarge ad nauseam on the superiority of literary and especially of classical training, forgetting that their preference for classics is but the survival of a practice and that their arguments in defence of a literary system are but preconceived opinions. Being incapable of appreciating the arguments used on the other side, it is unlikely that they will ever be able to admit their force.

So long as the forces of Nature were not tamed to the service of man, they could be negiected ; sanitary sins were alone found out and punished with unsparing severity. But now it is others wise. To succeed in competition with others we must be able to avail ourselves of every opportunity ; and wide understanding is demanded of us. Moreover, the growth of knowledge has induced severe mental hunger, and the feeling that the dainty dishes provided by Nature should be in no selfish manner restricted to the few is a growing one; altruism is a growing force. We feel that we are called upon to cuunteract the evils arising from the growth of our cities ; from the concentration of workers in large bodies; from the minute subdivision of labour; from the depressing conditions under which the masses daily

No. 1719 , voL. 66] 
toil. To provide relief and healthy occupation for leisure hours, and to secure that vacuity of mind and pettiness of motive shall no longer be the sore affliction they now are, we must take all the requirements into consideration and define with utmost minuteness the task in hand; broader and higher ideals than those now prevailing must be established and practical requirements must be met. To secure the right attitude of mind for this task will not be easy. Few realise, few know, how signal is our failure to appreciate our power, how deplorably we neglect our opportunities. The bareness of the fare we provide is nothing less than shameful in view of the rich possibilities which lie ready to hand. In saying that

A primrose by a river's brim,

A yellow printose was to him

And it was nothing more.

the poet has well pictured our average attitude towards our surroundings. To the majority, indeed, a primrose is scarcely a primrose; it is unseen. It is little short of impossible to account for our callous disregard of the wondrous beauty of the multitudinous objects displayed in Nature's realm, our willingness to remain ignorant of the meaning of the mysterious changes which are ever happening before our eyes. That familiarity should breed such contempt is passing strange; but how great the guilt in these days of those who allow the contempt to grow up, knowing as they must that the ignorance is easy to dispel, knowing also that those versed in the mysteries have ever sought to lay bare all that is within their ken. The failure on the part of those who have the charge of education to make a scientific use of the imagination is nothing short of complete; there is nothing to show that the imagination is ever called into play.

Surely it were time to make some real effort to imbue all with a proper understanding of their surroundings, to create in all minds a higher and reverent interest in life.

It is a sad reflection and a grievous blot on our civilisation that our spiritual advisers are mostly so little regardful, so destitute of understanding, of the works of that Omnipotent Power which all must recognise and humbly submit to, whether or no allegiance be acknowledged in doctrinal terms; they before all others should be prepared to consider their inmost meaning and to direct attention to their wondrous mechanism. We indeed need to send forth a new mission charged with the holy duty of enabling man to appreciate and acknowledge the beauty of the universe, as well as of preparing him to be a thoroughly effective worker, thus fitting him for the true, unselfish and reverent enjoyment of life. To use the apt words of the Master, quoted by the Poet at the Breakfast-table: "If for the Fall of $\mathrm{min}$, science comes to substitute the Rise of man, it means the utter disintegration of all the spiritual pessimisms which have been like a spasm in the heart and a cramp in the intellect of men for so many centuries."

If we can but make sweet use of our present adversity, though we may not be exempt from public haunt but live even in crowded cities, we shall unquestionably soon find

$$
\text { ... tongues in trees, books in the babbling brooks, }
$$

The wonderful prescience of our great poet is nowhere more clearly displayed than in these lines, and it is more than sur. prising that although generations have been charmed by the nusic of the words, so little has been done to realise their meaning or to give them a meaning in the minds of the majority.

It is but a question of attitude, for, as Carlyle somewhere says, "so soon as men get to discern the importance of a thing they do infallibly set about arranging it, facilitating it, forwarding it, and rest not till in some approximate degree they have accomplished that."

Unfortunately, there are all too many things of which we fail, through our faulty education, to discern the importance, but which a little understanding, the exercisc of some slight imaginative power, would enable us to appreciate. I will take the word Energy as an example. No word in the English language carries mare meaning to those versed in the principles of physical science, and yet how narrow its connotation in the minds of the uninstructed majority. As a guide of practical conduct, no word is of greater significance, and if its true im. plication fully seized us the word would ever rankle in our ears and serve to remind us of the maxim "Waste not, want not." In Great Britain we are using up our coal stores at the rate of over two hundred millions of tons per annum. Used at such a rate, the supply cannot last many generations; whence will our children derive their supplies of energy? Energy cannot be created. When we have squandered the wealth funded on our earth by the sun in xons past, we must fall back on the modicum we can snatch from the daily allowance the glowing orb dis. penses, for his largess will for the most part be wasted and will be very difficult to garner in our country, sun mills, wind mills and falling water being but irregular and ill-disciplined servants, trees growing but slowly. In all civilised countries the same criminal waste of fuel-of energy-is going on; but although we recognise that individual men have no right to live beyond their means and have little pity for bankrupts, no corresponding feeling exists on the subject of collective squandering. The spendthrift is regarded with equanimity, because he but distributes his gold among the many-so that the many gain while he alone is the loser-but the energy of fuel is spent irrecoverably, and all waste is not merely apparent, but real. To waste fuel is to court criminal bankruptcy; but to how many does it occur that we are all parties to such a crime? Does any schoolmaster or schoolmistress call attention to the fact? How many heads of schools could even write a respectable essay on such a topic? When I have suggested "A piece of coal" as the subject for a scholarship) examination essay, I have actually been told by literary critics that you have no right to ask for knowledge of facts in a schoolboy's essay, the object being but to find out to what extent he can "gas" in flowing periods! A scuttle full of coal excites no emotions in the literary mind; it should be one to call up harrowing visions, as well as a vista of memories extending far back into the ages of time, for in no other stone can we find a more wonderful sermon.

To descend to the ordinary level, how many householders ever take into consideration the wicked waste of fuel which goes on in their establishments? how many are really thrifty in the use of fuel ? I never see a "Kitchener," or hear it roar, but I shudder. The prevention of smoke' is of no consequence in comparison with the prevention of the waste of fuel. Even when every care is taken the waste is very great-simply because our incans of utilising the energy of fuel are so imperfect. The best steam engine can recover for us but very few per cent. of the energy stored up in the coal which is burnt in its boiler fire. If we could succeed in burning fuel electrically-in directly converting the latent energy into electricity-it is conceivable that the engine might be of nearly theoretical efficiency. But what imaginative power must be exercised to secure such a result ! Cannot we in some measure hasten the time of such discovery? Prof. Perry not long ago had the temerity to direct attention anew to the subject in NATURE, and made what many practical people will consider the impossible suggestion of a wildly imaginative, irresponsible Irishman - that a round million or so should be devoted to systematic experiments, with the object of discovering means of increasing the efficiency of our engines. If we consider what is the cost of a modern battleship; if we consider what has been spent on the war in South Africa; if we consider the extent to which the value of the fuel at our disposal would be increased if we could only double the efficiency of our engines and of our stoves, Prof. Perry's proposal cannot be regarded as otherwise than modest and sensible. But what is of real importance is the implied suggestion that the subject should be seriously inquired into at national expense. It must, and at no distant date, be admitted that our fuel stores are national assets over which there should be some national control.

I may take Food as another subject of which we fail to discern the importance, and which is outside the schoolmaster's ken, although teachers have stomachs as well as other men, and boys in particular are believed to take some interest in the existence of that organ. It is but a variant on that of energy, as the food we take is mainly of value as the source of the energy we expend -as fuel, comparatively little being required for the construc. tion and repair of the bodily machinery.

$$
\text { Goci has made }
$$

This world a strife of atoms and of spheres

With every breath I sigh myself away

And take my tribute from the wandering wind

And take my tribute from the wandering
To fan the flame of life's consuming fire.

Oliver. Wendell Holmes.

How many will appreciate this pregnant passage ; in how many schools is instruction given which would make it possible to recognise its beauty and completeness as a statement of the philosophy of the respiratory process? Our ignorance of ourselves and of the functions of food is indeed phenomenal. Life involves the unceasing occurrence of a series of changes for the 
most part chemical. If the proper study of man be man-as the highest dignitary of our Church some time ago asserted it was-the ordinary person would be prone to assume that those in charge of education would so direct studics as to give man some interest in his own wonderful mechanism; instead they almost uniformly direct that true "culture" consists in knowing what he has thought and written of himself in classic tongues, in ages gone by before the slightest vestige of understanding of the phenomena of life had been obtained. And we moderns calmly suffer this, and at the same time wondier at the way in which primitive peoples allow their medicine men and wizards to dominate them. Taking into account what is known, ours perhaps is relatively a deeper savagery than is that of most untutored races ; our educational priesthood are for the most par never trained to a knowledge of the mysteries and deny admis sion through ignorance rather than wilfully.

From food to the preparation of food is an easy step-in point of fact, the knowledge how to prepare food properly is of far more importance than any knowledige of what food is and does, as on it depends much of the happiness and health of mankind. Cooking is a branch of applied chemistry. We live in a scientific age--an age of knowingness. We might therefore expect that our girls at least would be so trained at school that with little effort they could become knowing cooks. I am not aware that the authorities who lay down the regulations for University locals or similar examinations have allowed any such vulgar considerations to guide them in drafting their examination schemes: niceties of grammatical construction, recondite problems in Geography and History, the views of an ancient philosopher who gave himself up to angle worship, are alone thusht of on such occasions; and yet there are times, it is said, when these august persons deign to take some notice of culinary efforts, and they cannot be unaware that conkery is a subject of some importance, which night well at least be led up to at school. To justify my reference to the subject, let me read a passage from "An Address on Education," delivered, not by a narrow-minded Goth who is so lost to reason as to doubt the sufficiency of an exclusively literary training as a pre paration for life, but by a classic, the Headmaster of a great public school, Thring of Uppingham, in speaking of the II Iigher Education of Women at St. Albans in 1886 .

"We English are proud of our homes. We sing songs about them, we write on them; in fact, we are very justly prout of our homes. Has it ever entered your minds that home to the great majority in a very large degree, and to all in some degree, is but a loftier name for cookery? In a cottage good cookery means economy, luxury, health, comfort, love. ... Cookery to the vast majority of mankind means home, and when the weary worker comes back from work wanting to refit, cookery alone can turn him out fit for work again. From this point of view home is cookery."

Cookery is certainly a subject of which those in charge of education have not yet in any way discerned the importance. Our cooks are inferior and wasteful simply because they fail to exercise sufficient imaginative power. If we wish to make good cooks of our girls, we must teach them to think for themselves and to be imaginative--to make a scientific use of their inagination; they will then come to see that the subject is a vastly interesting one. full of opportunity for research. The kitchen, of all places, is the one, in fact, in which the heuristic method should most flourish.

Could we find tongues in trees we should doubtless find them eloquent on the subject of food supply, and far more delicate in their tastes than any mortals. But how many of us, looking at a sreen leaf, can in any way call to mind the wonderful mechanisin which enables the plant to secure the main bulk of its solid substance from the fleeting stores in the circumambient atmosphere; or the manner in which it is dependent on light; or its mineral needs; or its great need of water and its wonderful transpiratory activity? And yet the chief industry of the world is agriculture-the feeding and tending of plants. At least those who lead a rural life should have their imagination excited on such subjects at school; it is even possible that much of the asserted dulness of a country life might pass away if an interest in plant activity were properly cultivated. And schoolmasters might even find comfort in the reflection that, as Messrs. Brown and Escombe have recently shown, the translocation of the material first formed in the leaves, metabolism and yrowth are become so intimately correlated that the perfect working of the entire plant is oniy possible in an atmosphere containing the normal amount of three parts of carbon dioxide per ten thousand ; they might recognise in the plant an organism after their own heart, with ripened conservative instincts, and unwilling to accept any other than the limited diet long favoured by the craft.

In these days, not only the obvious, but also the microscopic forms of life claim attention, and it is imperative that all should be at least aware of their existence and mindful of the deadly power that some of them exercise. All should be able to read with intelligence the wonderful story of the beneficent labours of the great Pasteur - a true saviour of mankind-and appreciate their value. The lessons of sanitary science will never be properly brought home to us and heeded in daily life urtil a more direct intimacy with micro-organisms is encouraged at school.

And whether or no there be "good in everything," children must at least be encouraged to seek it ; to use their cyes always, and to reflect on what they see. A proper use will be made of leisure and of holidays when they are so trained, and even "Days in the Country" will be days of enjoyment and peace for all, never of merc vacuous wanderings, let alone of wanton destruction, and will leave no memories of broken glass and waste paper behind them. And in the end the national drink bill may be considerably diminished if Shakespeare's words come to have some slight meaning for all.

Let us consider what we can do to further this most desirable end. Section L is in advance of the times, being concerned with a non-existent science-the Science of Edlucation. The science will come into existence only when a rational theory of education is developed and applied ; but it is clearly on the very eve of coming into existence, otherwise the section could not have been established; and we may contribute much to its developinent.

Surely, the primary article of our creed will be that - as Thring has said - "the whole human being is the teacher's care." for all must admit that the faculties generally should be cultivated and educated. At present we make the fundamental mistake of disregarding this truth, but there is evidence that sounder views are beginning to prevail. It is very noleworthy, for example, that in the recent report of the Committee on Military Education it is laid down that five subjects are to be regarded as necessary elements of a sound general education, viz. English, Mathematics, a Modern language, Latin and Experimental Science. Moreover, it is recognised that each of these subjects has a peculiar educational value of its own. Such a conclusion takes the breath away; incleed, it is almost beyond belief that Headmasters of Public Schools could commit their brethren by attaching their names to a report containing such a paragraph as the following:-

"The fifth subject, which may be considered as an essential part of a sound general education, is Experimental Science, that is to say, the Science of Physics and Chemistry treated experimentally. As a means of mental training, and also viewed as useful knowledge, this may be considered a necessary part of the intellectual equipment of every educated man, and especially so of the officer, whose profession in all its branches is daily becoming more and more dependent on Science."

Just consider what this recommendation means; that it is now publicly admitted by high authority that all boys should have the opportunity given to them at school of gaining knowledge by experience - by actually doing things themselves, not merely by reading about them or being told about them, because this, and nothing short of this, is what is aimed at by all who advocate the intruduction of Experimental Science as a necessary part of school training. The reign of the cleric as absolute monarch of the school kingdom will be at an end if such doctrine be accepted and acted upon, and there will be some chance of our regaining the reputation of being a practical people. Members of the British Association will be carried back in a dream some thirty odd years, to 1867 , when a report from a Committee, consisting of the General Otficers of the Association, the Trustees, the Rev. F. W. Farrar, the Rev. T. N. IIutchin. son, Prof. Iuxley, Mr. Joseph Payne, Prof. Tyndall and $\mathrm{Mr}$. J. M. Wilson, specially appointed to consider the best method of extending Scientific Education in schools, was presented by the Council to the General Committee, and it was resolved: "That the President of the Association be requested to communicate the Report to the President of the Privy Council," Sc. One among the reasons then given why general education in schools ought to include some training in science was, "as providing the best discipline in observation and collection of facts,

NO. I7I9, voL. 66] 
in the combination of inductive with deductive reasoning, and in accuracy both of thought and language." History does not record what the Privy Council did with the memurial. Had the Council been mindful of its duty to the country and paid serious attention to so weighty a representation, our present position might have been a very different one; the German and American bogies would have assumed less portentous dimen. sions in our eyes, and we might have found ourselves far better prepared than we were to cope with the conditions in South Africa. Accuracy of thought and language, according to the evidence given before the Committee on Military Education, are qualities in which military candidates are particularly lacking, notwithstanding the asserted value of I,atin-the chief subject of study in the Public Schools--as mental discipline.

Unless we are prepared to disregard, not only all the lessons of the recent war, but also the lessons we have been receiving during years past in the wider war of commercial competition ; unless we are prepared to disregard the still wider consideration that education must be an effective preparation for life and not merely for business, the findings of the Committee on Military Education must be embodied in our practice. Undoubtedly the real issue decided by the Committee was the question whether the antecedent, and not the technical, training of military candidates was properly conducted. In other words, ou Public School system was on its trial. Although not referred to in so many words, this system is most effectively condemned in spirit in every line of the Report, and far more between the lines. But the Committee have merely recognised what has been known for years and years; not a single novel point is brought out-not a single novel issue is raised in their report. By making definite recommendations, however, they have lifted the subject on to a higher plane, and it is these recommendations which require the most careful consideration and revision; for it carried out, as they stand, there will be little improvement in our condition. The Committee have certainly done more than they were asked to do, but not more than they were bound to do. By the terms of reference they were to consider and report what changes, if any, are desirable in the system of training candidates for the Army at the Public Schools. Instead they bave recognised that education at secondary schools has in a great measure conformed to the course generally pre. scribed by public professional examinations originally designed to secure the selection of candidates who had availed them. selves of the advantages of a good general education; and that the State has been careful in the matter of examinations that they should be so framed as not to disqualify or hinder the unsuccessful candidate from entrance into other professions; or, in other words, that neither more nor less is to be exacted from candidates for entrance into the Army than from candidates for other professions. Consequently the requirements to be laid down for Army candidates are such as can be met from a sound general education, and in no way special. The Committee have, in fact, pronounced judgment on the subject of all others which is of greatest consequence to the nation at the moment. But they were not actually appointed for such a purpose, although they should have been, as it was to be foreseen that the major issue must be tried if the minor were to be settled. The modern spirit in education was not sufficiently represented on the Committee. Of the witnesses examined, too few had any practical acquaintance with the work of education, although a great many who could judge of its effects gave evidence; and the practical side of education was scarcely considered. Only one witness was examined on behalf of "Science," and Mathematics was unrepresented. Such being the case, it is surprising that the Committee should have gone so far in their recommenda. tions, and a proof how overwhelming the case must be in favour of change.

Among the signs of the time showing that liberal views are coming into vogue, I may refer to the provision made in the new buildings designed by Mr. Aston Webb and Mr. Ingress Bell for Christ's Ilospital School, which was removed from London in May last. The new home of this ancient foundation is situated in the county of Sussex, about four miles south-west of Horsham, and comprises an area of 1300 acres of landmeadow, arable and woodland. Nearly $600,000 l$. have been expended on the new school up to date. Provision is made for 800 boys, and together with the necessary staff, these will form a colony of some thousand persons. The school provides its own water supply, disposes of its sewage by the bacterial system on its own premises, and is lit entirely by electricity generated on the spot. Oniy food and clothing are derived from the outside. If senior boys, in the future, are allowed to gain some insight into the interior management and economy of such an institution, what wonderful opportunities they will enjoy! And I hope the day is not far distant when boys will learn to understand everything connected with the school in which they pass so many years of their lives. A school should be the last to deny to boys every opportunity of gaining such invaluable experience. Fortunately, Christ's Hospital School is conducted on the hostel system; the masters are therefore not charged with household cares, and have no temptation to withdraw their thoughts from the work of education. The school has no taint of commercialism about it. It will be a happy day for our country when this is true of all our schools.

The school buildings are. placed nearly in the centre of the site and cover an area of about eleven acres. They are disposed along a slightly convex line facing southwards, the extremities curving gently towards the east and west respectively. The main range has a frontage of 2200 feet. At the eastern end, detached from the main range and somewhat retired, are the Infirmary and Sanatorium, which has a frontage of 500 feet. There are extensive playing fields and also a (iymnasium and Swimming Bath.

The scholastic buildings are grouped in the centre around a " ()uad." 300 feet by 240 feet.

The Dining Hall, 154 feet by 56 feet, behind which are the Kitchens and subsidiary offices, is placed on the north side of the Ouad. The Chapel has sole possession of the western side. The School IIali, I 30 by 50 feet, is at the centre of the southern side, class rooms being provided in two tuildings parallel to it, but separated by intervals of 40 feet.

The Science School faces the Chapel, filling the eastern side. The Art School and Library are arranged at right angles to it, somewhat in the background. The Science School consists of four main "laboratories," with subsidiary smaller rooms attached to each. No lecture rooms are provided, as Science is to be studied at the work bench; but each of the laboratories has a space arranged so that demonstrations may be conducted within it. The laboratories are fitted up as workshops, as well as in the ordinary way, so that boys may use tools as well as test-tubes, and the effort has been made to keep the fittings as simple as possible. Workshops for specific manual instruction will be provided in addition to the Science Schools. Ex. perimental science will be taurht throughout the school. It will be obvious that body, mind and soul have all been cared for. Whilst due provision has been made for the intake of that energy which is so indispensable to the indulgence in mental effort as well as to the maintenance of the vital machinery, science has received recognition at the hands of the designers of the Buildings, of the Governing Body and of the Head Master in a manner heretofore unusual ; it has actually been placed on an equality even with religion and with literary study, and it may be hoped that the reverent regard of the beauties and wonders of Nature gained in the Science workshops and in the surrounding country will but deepen the feelings of devotion proper to the Chapel and greatly help in lifting the life of the school to a high level. May the example not be without effect.

It has been my privilege to act as the nominee of the Royal Society of London on the Governing Body of the School during several, years past, and I may be permitted to bear witness to the manner in which one and all have been mindful of the needs of the times in arranging the new buildings. I believe few Governing Bodies of Schools will do otherwise than promote advance, if properly advised. Resistance to progress comes from within the schools. The public must force the schools to reform.

Let me now return to the recommendations of the Committee on Military Education. It is to be noted that they clearly involve the recognition of two sides to education $-a$ literary and a practical. I use the term practical advisedly, because it would be wrong to draw a distinction between a literary and a scientific side, as the whole of education should be scientific, and science - true knowledge - and scientific method-true method-should pervade and dominate the whole of our teaching, whatever the subject-matter; and as the object of introducing experimental science into the school is to give the scholars an opportunity of gaining their knowledge at first hand-by practical heuristic methods, as distinguished from literary didactic methods-the introduction of such discipline may be properly said to involve the recognition of a practical side.

No. I 7 19, voL. 66] 
The term practical must not be understood as the antithesis of theoretical. Practice is inseparable from theory in all true teaching, the advance from one practical step to the next being always over a bridge of theory. But if it be granted that educa. tion necessarily has two sides, it follows that the Committee on Militury Education are illogical in their recommendation that Latin and Experimental Science may be treated as alternative subjects ; they are but complementary, not alternative, subjects. The only possible alternative to Latin would be a subject in the literary branch-another language, in fact.

But the recommendations of the Committee are also far from satisfactory on the subject of languages. "The study of languages," they say, "forms a third main feature of a sound general education. Of these the most important, from an educational point of view, is Latin. Modern languages, though much inferior to Latin as a means of mental discipline (at least as generally taught), must none the less be regarded as an important part of a sound general education." In face of this conclusion it would have been logical to make a modern lan. guage rather than Latin the alternative to Experimental Science, but obviously the Committee dared not omit the modern language. It is true the recognition of Fxperimental Science and $I$ atin as possible alternatives may be regarded as a high compliment to the latter, but it was never intended to be such; in truth it marks the recognition of the inevitable; that Latin will ere long be deposed irom its high estate and intellectual freedom granted to our schools, greatly to the advantage of Latin, I believe. There is no doubt that the relative value of Latin as an educational subject is grossly exaggerated; those who dwell on its merits are rarely conversant with other subjects to a sufficient extent to be able to appreciate the effects these would produce if equally well taught. As a matter of fact, in the case of Latin the most capable teachers have been chosen to teach the most capable boys, and the results obtained have been unfairly quoted in proof of the superior value of the subject. We have yet to discover the highest value of other subjects, their depth of power as disciplinary agents having been most imperfectly sounded. And if we consider results, do not they afford proof that the belief in Iatin (as taught) is misplaced? It has been the staple subject of education and has been supposed to afford the most valuable training possible in composition. ${ }^{2}$ Nevertheless the complaint is general, and not only here but also in Germany-where Latin is far more taught and believed in-that composition is the one subject of all others which the schools do not teach. The fact is, Latin is a subject which appeals to the minority of scholars, and the time of the majority is wasted in studying it. I would give to all an opportunity of proving their aptitude in Latin and Greek, or at least some opportunity of appreciating the construction of these languages; but I am inclined to favour the proposal-made by high authority, I believe-that such studies should follow that of modern languages rather than precede it. The true study of classical languages should be reserved for the University. In any case, it is beyond question that a very large proportion of those who would make magnificent officers are incapable of learning Latin to advantage; such will in future enjoy the inestimable advantage of studying Experimental Science; but if those who take up Latin are in consequence to lose all opportunity of acquiring some power of reading the secrets of Nature and of thereby developing thought-power and mental alertness - and such must be the effect of the adoption of the recommendations of the Committee-they will prove to be of little value to the army in comparison with their colleagues whose eyes have been trained as well as their "intellect." In the course of the evidence given to the Committee, Dr. Warre expressed the view that Science would kill Latin eventually. Nothing could be more unfortunate, but the course adopted by the Committee is that most calculated to bring about such a result, as Latin is thereby put in competition with a subject which must ere long be regarded as a necessary subject of school

1 Dr. Warre was continually harping on this point in his questions to witnesses examined by the Committe. Thus $\left(Q \cdot 3^{1} 24\right)$ : "I want to put Geography and History into English, and your composition would be tested in that way. We think, for instance, that Composition is admir ably taught by translation from Latin or Grek. (To the witness:) Would
you agree with that, that translation from another language is teaching
English Composition?"

Again (Q, 3r29): "When officers have talked to us of the uselessness of Greek and Latin, they have neglected the fact that Greek and Latin ar the great instructors in English." Witness (the Rev. A. Robertson): "I instruction under all conditions. Latin should be made one of the optional subjects along with Greek.

In their scheme of marks for the examination, the Committee put Latin, French or German and Experimental Science on an equality by assigning 2000 marks to each; but English and Mathenatics are rated at a higher value, each receiving 3000 marks. It would have been better to have assigned equal values to the several group-subjects regarded as essential to a sound general education. It should scarcely be necessary to put a premium on the proper study of a man's own language; the subject bas naturally a great advantage over others. As to Mathematics, there is no doubt that this also is a subject of which the relative value as mental- training has been greatly over-valued, and that the methorls adopted in teaching it have been very faulty ; consequently much time has been wasted and its true value has not leen appreciated, as it has been made to appear unnecessarily difficult and fortsidding. The evidence before the Committee against Mathematics being carried too far was very strong. Thus Captain I,ee, in examin. ing Major-General Sir C. Grove (speaking of the training at Woolwich), said ((). 604): "There was an inmense amount of pure mathematics and so forth, which one never has occasion to utilise afterwards, unless one becomes an Instructor of Cadets at Wonlwich, where you teach them the same useless things you have learned yourself." This elicited from General Grove the reply: "Well, there is a strange tendency in Mathematics-I do not know why-that wherever you introduce them they encroach horribly. I ain always struggling to cut down advanced mathematics." And more to the same effect. Again, Lieutenant-Colonel S. Moores, when asked whether he considered the syllabus for the entrance examinations at Woolwich and Sandhurst to be reasonable (Q. 2353), at once replied, "No, sir; Mathematics are, in my opinion, very much over-valued as a subject for Army examinations, excepting for the Royal Engineers."

After all, if reasonable standards were adopted both in Mathematics and Latin, these subjects would not create the difficulty they do in examinations at present by absorbing so much of the time in school that no proper attention can be given to suljjects in reality at least of equal importance. It should be insisted that fundamentals be thoroughly taught, and by practical methods, so that the knowledge acquired may be real and usable ; it is astonishing how far students may be carried in Mathematics, and how real and interesting the subject becomes, when they grasp the fact that it has a practical bearing.

While dealing with Mathematics, I cannot refrain from quoting a statement made by Captain Lee ( $(2.4209)$, with regard to the relative values of this subject and science to military men, as the opinion he expressed is of very general application. "I think it is quite true," said Captain Lee, "that a great number of Artillery officers do go through their service without using Science, but I think they feel that any science they know proves of much more practical use to them in their profession than the Mathematics they have learned. As far as I know, in the most scientific branch of the Artillery, the Garrison Artillery, there are practically no occasions where a knowledge of Mathematics is required beyond the Mathematics necessary to solve a simple formula, whereas the lack of know. ledge of Electricity, Steam and Ifydraulics is often a serious handicap to the officer." I will venture to enlarge on this and say that, assuming Latin, Mathematics and Experimental Science were taught equally well, by equally sound methods, and that they proved to be of equal value as forms of mental training (though of course, devcloping somewhat different faculties), the training gained through Experimental Science would be far the most valuable because the recipients would be brought thereby most intimately into contact with the world and most fitted to help themselves by having their thoughtpower developed. Of course this is but an opinion, but one which, I venture to think, many share with me; and yet I make no superior claim for the subject, and ask only that it should rank equally with literary and mathematical training among the necessary subjects of education.

It still remains to consider the specific recommendations of the Committee with regard to Experimental Science, as these are most unsatisfactory. Nothing could be more satisfactory than the manner in which the subject is dealt with by the Committee in their general report, paragraph 20, already quoted (p. 592). But on turning to the scheme of the proposed 
examination (Appendix A), it appears that not one Experimental Science, but two Experimental Sciences are contemplated, viz. Physics and Chemistry, either of which may be taken in preference to Latin and together with English, Mathematics, and French or German. A most important issue is involved in this recommendation, and it cannot be too strongly opposed.

It is very strange, and a proof of how little we are accustomed to act consistently or to organise, that having found a good thing we rarely make use of it. In the early days of scientific teaching, the elementary parts of chemistry and physics were taught as one subject ; but gradually, as the individual sciences developed, this healthy practice fell into abeyance. Then time brought its revenge; it was seen that a very one-sided creature was being trained up; that the subjects were in reality interdependent. Moreover, a revolt had been setting in against the formal stereotyped manner in which chenistry was being taught in the schools; this came to a head about 1887 , and a better policy was inaugurated by the Reports and scheme presented to Section B of this Association in 1889 and 1890 , which condemned "test-tubing" in favour of problem work and led to the introduction of the quantitative exercises which are now generally admitted to be of the first importance. Although the scheme dealt primarily with chemistry, being the work of the Chemical Section, it yet had a physical basis; physical measurement, in fact, was its life blood, and all the earlier exercises prescribed in it were in essence physical exercises ; moreover, the importance of paying some attention to bio-chemical and bio-physical phenomena was not overlooked. As teachers have gained experience of the educational value of the heuristic methods advocated in the British Association scheme, they have been led to apply them more and more widely, and the teaching of Elementary Science has in con. sequence been regarded with growing favour of late years; more and more has been done to give it the necessary breadth so as to constitute it an effective system of "Nature Study."

The University of London-not the reconstituted body of the present day, but the much-abused examining body of the past-after careful inquiry a few years ago advisably substituted the subject of General Elementary Science for the specific sciences previously prescribed for the Matriculation Examination, and by so doing took a forward step which has generally been admitted by those who can really appreciate the issue to be one of the most important possible from an educational point of view. But the syllabus was imperfectly drawn up-although it had many good points-and the examination was entrusted to men who, besides having little sympathy with the subject, had scant knowledge of school requirements and possibilities. Consequently, the examination was a failure, as. everyone foresaw it would be if conducted without proper consideration. The new University has taken the most unwise step of reverting to single subjects. It has done far worse than this, however, in making "Science" an alternative subject. Such a reversal of the policy so long pursued by its forerunner can only be described as a National disaster. I make this statement with the utmost consideration, and trust that the fact that it is so pronounced from the Chair of this Section may give increased force to my opinion.

It may be claimed that the action taken by the Committee on Military Education is in harmony with that approved of by the Senate of the University of London. The only comfort left open to us is that afforded by the proverb that two wrongs do not make a right. Let us hope that wiser counsels will ere long prevail. The consequences of perseverance in so narrow a policy must be very serious. Consider the effect even from a limited professional point of view. It is widely felt that, owing to the growth of knowledge, it is necessary to specialise if we are to do effective work ; but this does not mean that we should be uncultured. We know that the very contrary is the case, and that there was never a time when general knowledge was of greater value than it is at the present day. Yet how little this is recognised. The physicist is already unable to understand the chemist. And although the biologist is attempting to unravel almost transcendental problems in chemistry, he has but the most rudimentary knowledge of the subject. What intellectual pigmies we shall be if we pursue so short-sighted a policy; how ineffective must be our treatment of borderland problems. How little right men of science will have to reproach those who have received only a classical and literary training with lack of general culture if we remain so narrow within our own domain. And from a general point of view the outlook is still more serious. The object of introducing Experimental Science into schools is to give training in knowledge of the world and to cultivate appreciation of its beauties and mysteries. To do this involves resort in some measure to all the sciences. Chemistry and physics are put first merely because they are of fundamental importance, chemical and physical changes being at the root of all natural phenomena.

As to the value of "Science" to military men, it is easy to understand that they should have little conception what it may do for them; having never received proper training hitherto, they cannot have had the opportunity of testing its usefulness or of appreciating its merits. But making all allowances, it is difficult to understand an answer such as that given by Lieutenant-Colonel Murray (Q. 4806 ) to the Committee on Military Education, viz. that "Science is a narrowing study for the young mind, and we want to widen and open the mind as much as possible; let them learn their science afterwards" (that is, after the entrance examination). The contention of the advocates of "Science" has always been that of all subjects it tends most to widen and open the mind. Why attention should be specially called to this answer by the Committee in their report is a riddle; I hope it was because they desired to show they could rise superior to the occasion. But the idea that science "can be learnt afterwards" is a very common one, and one of the most pernicious abroad. Learning from books and teachers is a lazy method of learn. ing, and the average scholar is corrupted at an early age by exclusive resort to such methods. Much of the mental inertness of the day is acquired at school by over-indulgence in book study. But apart from this, early youth is the period when the mind is most alert and the desire to acquire and experiment greatest; it is the time when the powers of ob. serving and of reasoning can be most easily developed into fixed habits ; in fact, if they are not then developed, it is only in exceptional cases that the omission can be rectified in after life. It is too cruel that Mr. Shenstone, the one witness on the subject heard by the Committee on Military Education, should have given expression to the ill-considered opinion that the beginning of the study of Science necessarily comes somewhat later than that of Latin. The statement shows how prone we are to draw false conclusions, how little we think before we speak. The study of Science begins when the infant opens its eyes; every step it takes when it toddles is an attempt to apply the methods of experimental science; some training in scientific method is given in well-conducted Kindergarten schools; but when school is entered, the curtain is suddenly drawn upon all such rational study; if it be the fate of the child to enter a Preparatory school prior to entering a Public school, he is at once referred back to the times of the Romans and Greeks, his teachers being oblivious to the real lesson to be learnt from the study of the scholastic methods of classical times-that the training given to the youth should be such as to fit him to do his work as a man. Ilow can our officers, how can any of us, be otherwise than ill prepared to do our duty in the world when we are so treated as youths?

Of course all such narrow views, all such narrow actions, as those I have referred to are but consequences of the lack of imaginative power-of our failure to make any scientific use of our imagination. Surely it were time we recognised this, and that we sought to do our duty towards our children. An Arnold who could introduce morality into school method, not merely into school manners, would be a precious gift to the world in these days. Steeped as we are in medixvalism, we need some cataclysm-some outburst of glowing sand and steam such as the world has recently witnessed in the islands of Martinique and St. Vincent-which would sweep away preconceived opinions and give clearness to the atmosphere. American industry is distinguished by the readiness with which manufacturers scrap their machinery and refit. Why cannot we agree to scrap our scholastic and academic ideals, if not our schools and schoolmasters, and refit on scientific lines? If we are to weld our Empire into a coherent whole and maintain it intact, we must do so. Unless we recognise prophets-if progress be allowed to depend on the multitude - we shall perish. And time presses; we cannot with safety much longer remain a "nation of amateurs." An appeal must ere long be made to the masses to enforce the provision of leaders; it must be urged upon

No. 1719 , voL. 66] 
the men that they see to it that their masters are educated ; for however democratic we may be in our ideals, history teaches, in a manner which admits of no denial, that leaders are the salt of the earth, and in these days leaders need a deal of training to be effective.

Unfortunately, it too often happens that those placed in authority are the very last to attempt to march with the times. Bodies such as our Universities, the Education Department and the Civil Service Commissioners might have been expected to lead the way, to keep the most watchful eye on all that was happening, and to note and apply all improvements. The very contrary has been the case. As a rule, they have advanced only under severe pressure from outside, and scarcely a change can be credited to their initiative. It does not seem to have occurred to them that an Intelligence Department would be a desirable appendage. All suffer from the fatal blot that discretion and authority are vested only in a few heads of departments; the younger and more active spirits have no opportunity granted them while their minds are plastic, full of courage and instinct with advance; so when the time comes that they can act they have lost the desire through inanition. This is the terrible disease from which all our public offices and many industries suffer. It is right to accord experience its proper value, but it is wrong to put aside youthful energy and inventiveness. Our American cousins owe their advance largely to the recognition of these facts.

At bottom the spirit of commercialism is the cause of much of the contorted action we complair of. Neither Cambridge nor Oxford will take the step which has long been pressed upon them-and never more eloquently than by the Bishop of Hereford in his paper read before this Section last year-to make their entrance examination one which would be in accordance with our knowledge and the recognised needs of the times, and one which would have the effect of leading schools generally to impart the rudiments of a sound general education. They cannot act. together and are afraid to act singly, each earing that it would prejudice its entry if it took a step in advance and in any way sought to influence the Schools. The Colleges vie with each other in securing the best scholars in the hope of scoring in the general competition. And the Schools have discovered that successes gained in examinations are the most effective means of advertising, and are therefore being turned more and more into establishments resembling those engaged in the manufacture of paté de foie gras, in which the most crammable are tutored without the least consideration of the manner in which lifelong mental biliousness is engendered by the treatment. Parents, with strange perversity, worship the success achieved by Tom and Dick, Mary and Jane, and think they are doing their duty by their children in allowing them to be made use of -for private ends. The worst feature of the system is the narrow spirit of trades unionism which it has engendered, which leads to the worship for ever afterwards of those who have gained the prizes, instead of regarding them but as victors for the moment and requiring them at each step to give fresh proof of power. Nothing is more unwise than the way in which we overrate the pretensions of the "first class" man; we too often make a prig of him by so doing. Those who succeed in examinations are too frequently not those most fitted for the work of the world. A long experience has convinced me that the boys a few places down a class are, as a rule, the best material. Those at the top may have acquisitive power, but more often than not they lack individuality and the power of exercising initiative. We must base our judgment in the future on evidence of training and of general conduct, not on isolated examinations. If any sincerity of purpose be left in us, if any sense of the value of true training-of what constitutes true training - can be rescued from the scholastic wreck on which we find ourselves at present embarked, we must institute some form of leaving examination which will give the requisite freedom to the schools and every opportunity for the development of individuality, and at the same time necessitate thoroughness of training and patient regard of every grade of intelligence; leaders will show themselves and will not need to be examined for. Examinations as commercial enterprises must suffer an enforced bankruptcy.

Racing studs must be regarded as Iuxuries in schools and kept apart from the ordinary stables, these being regarded as the first charge upon the establishment, as the serious work of the world will fall upon their occupants. In other words, special provision must be made for scholars, and they must not be allowed to monopolise attention and set the pace to the detriment of the majority. When Carlyle made the statement that we had in our islands a population of so many millions, mostly fools, he stated what is only a half truth. He failed to realise that the foolishness is very largely begotten of neglect and want of opportunity, not innate. Our schools mostly fail to find out the intelligence latent in the great majority of their pupils, and give it little chance of developing by offering them a varied diet from which to select. During a long experience as a teacher, I have over and over again seen weaklings develop in course of time into strong men when they have been properly encouraged and an opportunity at last found for the exercise of their "talents." The Briton is in this respect a most mysterious creature ; you never know when it is safe to call him a fool. All are agreed that the mistakes in the recent war were not due to lack of intelligence, but to lack of training. There can be no doubt of that. All who have taught in our colleges will, I am sure, agree with me that the material sent up from the schools is in substance magnificent, but too often hopelessly unfit to benefit from higher teaching. The things said of those who enter for the military profession are as nothing in comparison with what could be said of those who enter for the professions generally. If our young people fail to show intelligence in later life, it is, as a rule, because the conditions under which we place them in earlier life are such as not only to leave their intelligence undeveloped, but, what is far worse, such as to mar their ability. The best return we can make to those who did such magnificent service in the late war will be to take to heart the real lessons taught by the mistakes, and to see to it that theirchildren and successors generally are trained in a happier school than that in which they were placed.

Examining bodies at the present time do not appear to realise the full measure of their responsibility. To examine well is at all times a difficult task, far more difficult than to teach well. The examiner wields a large measure of authority, and it is imperative that he should exercise this wisely. Examiners should therefore be chosen with extreme care and with due regard to their fitness for the work ; but this too rarely happens ; the choice falls too frequently on specialists, with little knowledge of educational requirements and possibilities. The examination of boys and girls is far too often put into the hands of those who have no real knowledge of the species and little sympathy with its ways.

There are three courses open to examining bodies-to lead, to maintain themselves just abreast of the times, to stagnate. As a matter of fact, the last is that almostinvariably chosen - a syllabus, when once adopted, remaining in force year after year. Consequently, examinations tend to retard rather than to favour the introduction of improved methods of teaching. It is impossible to justify a policy which has such results. The evil effect of examinations would be less if the syllabus were abolished and the limits of examinations very broadly indicated; this is done in some cases, and might be in all. The incompetent examiner and teacher are not in the least helped by the conventional curt syllabus, but the liberty of action of the competent examiner and teacher, and their desire to effect improvements, are materially limited by it. The competent examiner should know what is a fair demand to make of a particular class of students, and should be in a position to take count of the advances that are being made; and the competent teacher should be able to do all in his power to make the teaching effective, and be secure in feeling that his efforts could not fail to be appreciated. To take my own subject, the chemistry syllabus recently laid down for the London Matriculation examination is quite unsuited to its purpose and most hopelessly behind the times. The scheme put forward in the report of the Committee on Military Education is but a bag of dry bones. In the case of several subjects, the South Kensington schemes are full of the gravest faults, their hoary antiquity being their least objectionable feature. Surely a national institution, dispensing public funds, should be the last to hold back the nation; it should be provided with machinery which would enable it to march with the times. In making this criticism I should like to recognise the great work done by Sir William Abney in instituting reforms; but one swallow does not make a summer; a self-acting, governing mechanism is needed which would at all times maintain the balance of practice with progress.

If we consider the process by which decisions on such matters are arrived at, even in the bodies representative of very large interes's it is a curiously imperfect one. Usually very few

No. I 7 I9, VOL. 66] 
individuals are concerned. We are all still imbued with primitive instincts. In some way two parties arise, and the question is, which shall conquer? More often than not the true inwardness of the issue presented is left out of account-the considered opinion of the day is scarcely asked for, or if opinions are collected they are not weighted. Therefore calm reason is rarely the arbiter. The conditions of modern civilisa. tion require that some better method shall be devised, which will really enable us to do that which would be of the greatest good to the greatest number. We do not sufficiently remember that while we are tilting, the enemy at our gates is contem plating our failure to maintain and strengthen our fortifications, and guietly advancing his forces to the attack. Speaking of the Navy in the IIouse of Commons not long ago, Mr. Arnold Forster said: "There was a need for some reinforcement of the intellectual equipment which directed, or ought to direct, the enormous forces of our Empire." Surely we may take these words as true generally.

At the present time, when the responsibility of controlling all grades of education is about to be cast upon the community and the actual call to arms is imminent, it is imperative that a sound public policy should be framed and that nothing should be allowed to stand in the way of the public good. It cannot be denied that School Boards have done most admirable service; but there are many who are convinced that in not a few respects they have been disastrous failures and that we need a wider organisation, penetrated with sounder and especially with more practical views. The one essential condition of success is that the public itself treat the matter seriously, realising that their nown immediate interests are at stake and thati they will be the first to suffer if those who are chosen by them to formulate the new policy and to supervise the work of education are unqualified and, to emphasise my meaning, let me add, unpractical. If the State is to retain any measure of authority, it too must be prepared to exercise that authority wisely. The blame to be put upon School Boards in England for having allowed an unpractical system of education in the schools is as nothing compared with the blame to be put upon the Education Department for having allowed such a system to grow up by the adoption of academic ideals and academic machinery. Until recently, it was a disqualification for an inspector to have teaching experience. A good degree, if not political influence, was the one qualification. Consequently men were chosen whose practical instincts had never been developed, whu knew nothing of practical life and of common-place require ments, and nothing of zchildren and their ways; with rare exceptions, the inspectors could look at education only through Hiterary blinkers. To intensify the evil, the wicked system of payment by results was introduced. An inspector such as I have described, working under such a system, could not do otherwise than destroy teaching. ${ }^{1}$

The first necessary step to take will be to reorganise the Education Department, root and branch ; to imbue it through out with sound ideals and lead it to understand its great importance as the head centre of the Educational system; for disestablish as we may, and however much we may favour local self-government, a head centre there must be to correlate the efforts made throughout the country and to distribute wisdom; but its functions will be those of an exchange and inquiry office rather than directive and assertive. At least, such is my reading of the tendency of the Zeitgeist. Such a Department will have an Intelligence Board, whose members are partly official, partly unofficial, so that it may maintain itself in constant touch with outside opinion and effort. One function of this Board will be to preside at a monthly bonfire of red tape and official forms ; for in future, even if no other subject of Government concern be kept in a lively and living state, education must infallibly be. The whole staff of the office, including the inspectorate, will be required to avail itself of that most valuable institution, the sabbatical year, i.e. to spend every seventh year in some other employment, so that they may not forget that the world has ways sometimes different from those pictured within the office and which it is advisable to take note of in education. Refreshed and invigorated, they will return to work, prepared to sacrifice all sorts of traditions and to recognise the existence of short cuts across fields which had before appeared to be of interminable dimensions; and as it

1 The inspector destroys teashing, because he is bound by law and necestity to examine according to a given pattern; and the perfection of teacling is that it does not work by a given pattern (Thring). will be required that they spend a certain proportion of their close time in the company of children -if they hive none of their own-they will learn that a child has ways and views of its own, none the less interesting and worthy of consideration because they are somewhat different from those of grown-up people.

It is fortunate that the Technical Education Movement has been coincident in England with the development of the Szhool Board system. Those engaged in it have worked untrammelled by official requirements, and much original thought has been enlisted in its service. In essence it has always been a revolt against the academic ideals permeating University education and the schools generally; the faults of the schools, in fact, are the more obvious in the light of experience gained in technical education, which will now come to our aid in correcting th $\geq \mathrm{m}$.

The really serious tasks before those who direct the work of education in the immediate future will be the choice of a programme and the provision of capable teachers. If they enter on theșe tasks with a light heart, (xod help our nation; they will thereby give proof that they have no true conception of the great responsibility attaching to the position they occupy. Let no man offer himself for the work unless he feels certain that he is in some degree qualified.

As to the programme, it may be said that that is for the teachers to settle; and so it should be. But it cannot be denied that, by long-continued neglect to read the writing on the wall, they have lost the claim to legislate; they have shown that they do not know how to legislate. The public must lay down the programme in its broad outline; ; teachers mu it fill in the details. The task imposed upon the schnols will be to develop the faculties generally $\rightarrow$ not in the lop-sided manner customary heretofore - and especially to develop thought-power in all its forms and the due application of thought-power.

I believe that gradually a coinplete revolution must take place in school procedure, and that the school building of the future will be altogether different from the conventional building of to-day, which is but an expansion of the monkish cell and the cloister. Instead of being a place fitted only for the rearing of what I have elsewhere termed desk-ridden emasculates, the school will be for the most part modelled on the workshop, giving to this term the most varied meaning possible, and a great part of the time will be spent at the work bench, tool in hand. Nature's workshop will, of course, be constantly utilised, and the necessary provision will be made for outdoor exercise and physical training. Szientific method will underlie the whole of education.

It will be recognised that education has two sides, a literary and a practical; that the mind can work through fingers; in fact, through all the senses; that it is not embodied only in the so-called intellect, a narrow creation of the schools. The practical training will therefore be regarded as at least equal in iniportance to the literary. Ileads of schools will not only be potential bishops, but almost all careers will be open to them. In fact, I trust the system will be in operation which I have already advocated should be applied to the Elucation Department, and that the members of the school staff will be forced out into the world at stated intervals, so that they may not degenerate into pedants capable only of applying set rules much after the manner of that delightful creation Beckmesser in Wagner's opera "Die Meistersinger."

The çlass system will be largely abandoned. Children's school time will not be chopped up into regulated periods in a manner which finds no analogy in the work-a-tlay world, but they will have certain tasks confided to them to d.) and will be allowed considerable latitude in carrying them to completion. In fact, they will be treated as rational beings, and their individuality and self-respect developed from the outset. The Boer War will have taught us to adopt open-order teaching as well as open-order firing. Schools will glory in turning out individuals, not machines. The success of the Americans is largely due to the way in which Republican doctrines are applied to the up-bringing of children in America. We must follow their example, and set our children free and encourage them to be free at an early age. The human animal develops at a sufficiently slow rate in all conscience, and there is little need for man to retard his own development. School, with its checks upon freedom and individuality, should be quitted at seventeen at latest, I believe, and all subsequent systematic training should take place at college. Boys are kept at school after seventeen mainly for the purposes of the school. It is claimed that by

No. I'I9, vOL. 66] 
remaining they gain most valuable experience by acting as monitors and prefects.; but this experience is enjoyed only by the few, and might be obtained at an earlier age. Then it is said that seventeen is too early an age to enter Oxford or Cam. bridge, but this bas only been the case since schools have retained boys to prepare them for examinations and in order that they might assist in the management. I believe that the attempts which have been made in these latter days to do college work at schools and to establish engineering sides in order to find work for senior boys have had a most detrimental effect. It is said that the training given in technical schools is too far removed from practice ; but how much more must this be true of technical work done under school conditions? The excessive devotion to literary methods favoured by schools and the older Universities tends to develop unpractical habits which unfit many to face the rough-and-tumble life of the world, and is productive of a disinclination for practical avocations. By leaving school at a properly early period this danger is somewhat lessened; moreover, it is necessary in many walks of life that school should be left early in order that the school of practice may be entered sufficiently soon to secure the indispensable manual dexterity and habits. For a long time past we have been drifting away from the practical, and those who are acquainted with the work of the schools, especially the elementary schools, are aghast at the influence they are exercising in hindering the development of practical ability. We must in some way counteract this tendency. On the other hand, we have to meet the views of those who very properly urge that it is cruel to withdraw children from school even at the age we do. The two views must in some way be reconciled. The only way will be to so improve the teaching in schools that school becomes a palace of delight and the continuation school a necessity. The habits formed at schcol should be such that study would never be intermitted on leaving school. At present school so nauseates the majority that on quitting it they have neither desire nor aptitude to study left in them; the work done in it is so impossible to translate into ordinary practice, so foreign to outside requirements.

The problem can only be solved by the scientific use of the imagination. The solution I would venture to offer is that an honest attempt be made to teach, not only the three R's, but also a fourth, Reasoning - the use of thought-power-and that a properly wide meaning be given to all the R's.

Of all powers that can be acquired at school, that of reading is of first importance. Let teachers read what Carlyle says in the "Hero as Man of Letters," correcting his exaggerations by reading into his words some of the lessons taught by experimental science. Reading is not taught in schools in these days; if it were, people would not waste their time on the rubbish which now figures as literature and for which a rational substitute must be found. A well-read man is worshipped at the Universities and is held up to all comers as a pattern. Why should not children be encouraged to be "well read"? Let us admit this and sow books in their path. Thring, in giving utterance to his "Practical Thoughts on Education after Thirty Years' Work," speaks strongly on this point. "Great interes will make up for want of time. Create great interest," he says ; and these are noteworthy words. "As soon as children can read, throw away all lesson books for a time. Let them read-let them read aloud-really read, not tumble through the pages. Give them to read poetry, the lives of good men, narratives of noble deeds, historical stories and historical novels, books of travel, and all the fascinating literature of discovery and adven. ture. The person who has once learnt to read well is tempted to go on. And such books, selected by a carefully graduated scheme, would supply endless knowledge whilst kindling the mind, without any waste of time from drudgery and disgust. Geography, history and power of speech are all comprised in such books if properly used."

Thring here advocates what I would advocate-the incidental method of teaching. Why should there be any set lesson in subjects such as history and geography? Nothing is worse, more stereotyped, more cramping to the intellect than the set lesson of so many lines or pages, of a sort of Liebig's Essence of information, with the attendant obligation of committing the facts recorded in them to memory. The child, like the restive, bigh-mettled young steed, wants to be off and away-not to be held severely in hand. Why should not the method by which we get up a subject in later life be followed in schools? At least it should be properly tried. Let us give freedom to children, and at least during early years lead them to read hard and wisely ; they will do so gladly ; and give them pictures innumerable in illustration of their reading. And children must not only be taught to read books; they must learn also to regard and use them as sources of information; the habit of flying for information to books must be cultivated. They must be constantly referred to dictionaries and works of reference generally; they must be set to hunt up all sorts of stories. Of course the scholastic Beckmesser will object that such a system is impossible, that there would be an end to all discipline; but to say this is to show a want of understanding of children and of faith in them, and is proof of failure to recognise their power of accepting responsibility when it is properly put upon them. The secret of success lies in beginning sufficiently early; once let them appreciate what they are doing and the majority will work eagerly and spontaneously.

But when the full meaning is given to the first of the R's, it will be held to cover, not only the reading of printed or written character, but also the reading of some of Nature's signs, to the end that sermons may $b e$ discovered in stones and good in every. thing. That is to say, at the same time that they are acquiring the true art of reading, they must be learning the true art of experimenting - to find out things by putting questions of their own and obtaining direct answers. The teaching of the elements of experimental science must therefore accompany the teaching of reading. And great care must be exercised that the palate for experimenting, for results, is not spoilt by reading. The use of text-books must be most carefully avoided at this stage in order that that which should be elicited by experiment is not previously known and merely demonstrated-a most inferior method from any true educational point of view, and of little value as a means of developing thought-power. I regard Huxley's "Physiography," for example, as a type of the book to be avoided until method has been fully mastered. The great difficulty in the way of teaching the art of reading arises from the comparative paucity of readable books for young people. Text-books are not readable, and in fact tend to spoil reading; and the majority of books are written for grown-up people having considerable experience of the world. The mistake is too commonly made of expecting children to master " classics." On the other hand, we need not fear allowing advanced books to fall into the hands of children; they are the first to despise the namby pamby stuff that is too frequently offered to them. A new literature must be created, if education is to be put on a sound basis ; something beyond mere word-painting is required. Books are wanted, written in a bright, attractive and simple style, full of accurate information, which would carry us over the world and give clear pictures of all that is to be seen, as well as of the character and customs of its inhabitants; and books are wanted which, in like manner, would carry us back in time and sketch the history of the peoples of the earth. The various branches of science all need their popular exponents; our books are for the most part too technical, and whilst much has been done to advocate the introduction of "Science" into general education, little has been done to make this possible. Unfort unately, those who attempt to write readable books are too frequently not those who are possessed of sound knowledge, and it is time that it were realised by those who could write well and accurately that there is a duty incumbent upon them; on the other hand, something should be done to stem the torrent of text-books which is now flooding the field of education with the destroying force of a deluge and making proper reading impossible.

The true use of books has yet to be found and admitted; we do not sufficiently recognise their value as stores of information and savers of brain waste. Why should long trains of facts be cominitted to memory but to be forgotten ? It is impossible to believe that such a process is mental training; it must involve loss of energy and mental degradation. In future we must give the training at less cost and teach the art of going to books fos minute details whenever they are wanted. Nearly every subject is taught in an eminently selfish manner at the present time, the expert declaring that the learner must become acquainted with all the main facts of the subject, instead of recognising that it is far more important to acquire knowledge of first principles together with the power of acquiring the knowledge of facts whenever these become necessary.

The second $\mathrm{R}$ may be held to cover, not only mere writing, but also composition. Why is the art of composition taught so badly? Because it is impossible even for children to make

No. 1719, voL. 66] 
bricks without straw; they have little to write about under ordinary school conditions. The subject is also one, I believe, which must be taught incidentally, at least during the earlier years, and chiefly in connection with the experimental work; in fact, to make this last the training it should be an absolute record of all that is done, must be properly written out, and while the work is being done ton. Many teachers, I know, shy at this, and say that it is their business to teach "Science," and not literary style ; but they are wrong, and must inevitably accept the burden if they are to succeed in teaching "Science" at all. An experiment, like an act, " hath three branches"to conceive, to do, to utilise; a clearly defined motive must underlie it; it must be properly executed; the result must be interpreted and applied. It is only when the motive is clearly written out that it is clearly understood-that the meaning or intention of the experiment is clearly grasped; and this is equally true of the result. Of course, it is necessary to proceed slowly and not to demand too much from beginners; but it is surprising how the power grows. Drawing, of course, must be included under the second $\mathrm{K}$; but this also may with advantage be taught incidentally, and only receive individual attention at a later stage, when those who show aptitude in the incidental work have been selected out for higher instruction.

The third $\mathrm{R}$ must be held to cover, not merely the simple rules of arithmetic and all that is necessary of formal mathematics, but also measurement work. Mathematics claims to be an exact subject, and therefore must be treated exactly and made the means of inculcating training in exactness, and not on paper merely, but in fact. Moreover, physical science reposes on a basis of exact measurement, so that the introduction of experimental work into schools involves the introduction of measurement work as a matter of course.

The fourth $\mathrm{R}$-Reasoning-will necessarily be taught in connection with every subject of instruction, not specifically. It is introduced as marking the absolute need of developing thought-power; and, in point of fact, should be put before all others in importance.

Under such a system as I suggest, the time of study would be spent in two ways -in reading and experimenting. But what ever we do, let us be thorough the danger liesin attempting too much, too many things. Each step must be taken slowly and warily, and a secure position established before going further.

Ireland is fortunate at the present time in that far-reaching changes are being introduced into its educational system. A body of men are engaged in this work who are, I believe, in every way specially qualified to promote reforms and earnestly desirous of developing a sound policy. The Irish race have rich powers of imagination such as no other section of the nation possesses, and it is only necessary that these powers be trained to considered and balanced action to make the Irish capable of deeds before which the splendid achievements of the past will appear as nothing. Of course, the development of a true policy must come about slowly, and we must not be too impatient of results, but give every encouragement and all possible support to those engaged in the work. It is before all things necessary to remember that the school is a preparation for life, not for the inspector's visit; in the future, the inspector will act more as adviser and friend, let us hope, than as mentor.

Turning to my own subject, the programmes laid down for primary and intermediate schools appear to me to be well thought out and full of promise, the only fault that I might be inclined to find being that perhaps they are somewhat too ambitious. But very able men are directing the work, and they should be able to see that thoroughness is aimed at before all things. Nothing could be more gratifying than Mr. Heller's statement in the Report for 1900, "that the Irish teachers as a whole seem to possess a great natural taste and aptitude for science and the method of experimental inquiry." May they seek to set the example which is sorely needed to teachers in other parts of the kingdom. I fear there has been a good deal of hand-to-mouth teaching in the past; to avoid this, the teacher should not only have a carefully drawn-up scheme of work, but should keep a diary in which the work accomplished each week is carefully recorded. In this way the weaker teachers wilk check any tendency they may have to relax their efforts, and inspectors will be in the position to understand at once what progress is being made. Education, unfortunately, is subject to booms as the money market is; just now the "Nature-study" boom is on. We must be very careful not to let this carry us away ; whatever is done must be by way of real Nature-study, and must have very simple beginnings. In most of the work that is being boomed, the presence of the eternal book is only too evident, and such teaching must be worthless. Let the teachers remember that the great object in view is to acquire the art of experimenting and observing with a clearly defined and logrical purpose. If they once learn to experiment properly, all else will follow. The inspectors must give constructive help to the work; they too must be students and labourers in the cause of progress, not mere commentators. And there will be a great opportunity for experts to assist who can be helpful to schools. Every school should be provided with a workshop, simply equipped with flat-topped tables, in which all the subjects which are taught practicaliy can be taken. Elaborately fitted laboratories are not only unnecessary, but undesirable; the work should be done under conditions such as obtain in ordinary life. A due proportion of the school time must be devoted to experimental studies; no difficulty will arise when it is seen that so much else is taught incidentally; and that this is the case must be carefully borne in mind in arranging the curriculum -otherwise there will be much overlapping and waste of time. Lastly, every effort must be made to keep down the size of the classes. I trust that in Ireland the girls will receive as much attention as the boys. Experimental teaching is of even greater value to them than to boy;, as boys have more opportunities of doing work which is akin to it in the world. The work done by girls should of course bear directly on their domestic occupations.

If we are to improve our schools, the teachers must be trained to teach properly-or rather, let me say, must be put in the right way to teach, because practice and experience alone can give proficiency. This is the most difficult of all the problems to be faced in providing for the future. It is the one of all others to be thought out with the greatest care, and in solving it the help of all who can help must be secured. No amount of didactic teaching will make teachers; the training must be practical. To graft on the ordinary training a course of lectures on the theory and practice of teaching plus a certain amount of practice in a school is not enough. How can we attempt to teach the theory and practice of teaching when we are agreed that we do not know how to teach most subjects? Ilow can a master of method instruct us how to teach sub. jects of which he has only heard? It cannot be done ; in point of fact, we are talking about the thing-beating about the bush -instead of treating the problem as one which can only be solved by experiment. To teach method, you must know your subject; one man cannot know many subjects. Of course there are quite a number of good general rules to be learnt, but the application of these must rest with the specialist; and the only proper way of giving training in method is to teach the subject in the way it seems desirable that it should be taught. The end result of training should be the development of a spirit of absolute humility - of the feeling that no task is so difficult as that of teaching properly, no career in which finality is m rre impossible to attain to, no career which offers greater opportunity for perpetual self.improvement. The effect of the narrow and unimaginative system in vogue to-day is to send forth a set of young persons who arrogantly consider that they are "trained"; if they would only think of the amount of preparation involved in training for athletic competitions, or in training race-horses even, they would entertain more modest views and be aware that they have everything to learn when they commence their work. The Beckmessers reign supreme in our training colleges of to-day; they must be got rid of, and true modest experts introduced in their place. The test of efficiency must be a real one, not that of a mere final examination. The inspectors must see to it that the instruction is given always with a view to the fact that the students are to become teachers, which at present seems to be the last consideration borne in mind. Every effort must be made to secure a higher class of student for the training colleges; a fair secondary training must be insisted on. A narrow spirit of trade unionism pervades the primary school system at the present time, and School Boards and managers of Pupil Teachers' Centres make no effort to secure the assistance of secondary teachers.

My receipt for a training college would be : Develop thought. power and individuality; develop imagination. Teach what ever will do this most effectively, and let special subjects be studied in the way that may best be followed in teaching them subsequently.

No. I 719 , vOL. 66] 
It is to the lasting shame of our State organisation and of our School Boards that so little has been done to provide competent teachers.

The future rests with the Universities; but to save the nation the Universities must be practical, and broader conceptions must prevail in them. A course of training which will give true culture must be insisted on. The Universities have recently shown a disposition-to use a vulgarism - to throw themselves at the heads of the military authorities and to make special provision for the training of military students. It is much more their office to train teachers. Why should not the example to hand in the engineering school at Cambridge be followed ? Why should not a special Tripos be established for teachers in train ing ? I believe this to be the true solution of the problem.

The desire now manifest in several of our large towns to establish new Universities comes most opportunely, and should receive every possible encouragement from all who have the interests of our country at heart. I believe the objections to be altogether fanciful and the outcome of academic views. It is said that the value of the degree will go down like that of Consols. But in what does the value of a degree consist? Simply and solely in the evidence it affords of training. We regard the Oxford and Cambridge degrees as of value because they are proof that their possessors have lived for some time under certain conditions which are recognised to be productive of gond. The degrees of other Universities must soon come to be regarded as proof of sound and healthy training. It must become impossible to obtain degrees such as the University of London has been in the habit of awarding, which have been the result of mere garret-study; proof of training will be required of all candidates for degrees.

But I must now bring this Address to a conclusion. The only apology that I can offer for its length is that having had over thirty years' experience as a teacher, and being profoundly impressed by the serious character of the outlook, the opportunity being given me, I felt that, as the walrus said to the carpenter,

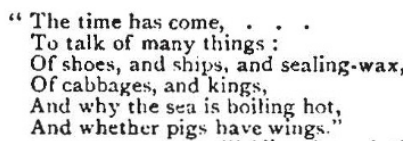

("Alice through the Irooking-glass.")

This list of subjects is no more varied and disconnected-the problems set no deeper-than those to which we must give our attention in dealing with education; and the sooner the fate of the oysters is that of our present educational "system" the better. Having shown by this quotation that I am not an absolute modern, but have some knowledge of the classics, let me finally say, in the words of another poet-of him who on various occasions gave utterance to much wisdom at the break fast table, that "I don't want you to believe anything I say, I only want you to try to see what makes me believe it."

Something more than an apology for an Education Act such as the powers are now engaged in shaping for us must be framed at no distant date, and a determinate policy arrived at. That policy may perhaps be found in the words put into Hamlet's mouth :-

Hamlet. Towhat base uses we may return, Horatio! Why may not imagination trace the noble dust of Alexander, till he find it stopping a bung hole?

IIoratio. 'Twerc to consider too curiously, to consider so.

Hamlet. No, faith, not a jot ; but to follow him thither with modesty enough, and likelihood to lead it, as thus: Alexander dicd, Alexander was buried, Alexander returneth into dust ; the dust is earth ; of earth we make loam; and why of that loam, whercto he was converted, might they not stop a beer barrel?

Imperious Cæesar, dead and turned to clay,

Might stop a hole to keep the wind away;

$O$, that that earth, which kept the world in awe,

Should patch a wall to expel the winter's flaw!

Shakespeare thus taught the use of the imagination before Tyndall! The fact that we can now carry our imagination far further afield and contemplate the survival of atoms once embodied in imperious Cxsar in the flowers and fruit which deck the fair face of Nature-a higher end than that Hamlet paintsmay serve to justify the adoption of a method he advocated. Modern progress is based on research-the application of imagination. Surely then there is every reason to make the spirit of research the dominant force in education !

\section{UNIVERSITY AND EDUCATIONAL INTELLIGENCE.}

Prof. C. F. MYers WARD, of the University College, Sheffield, has been appointed lecturer in physiology at the Charing Cross Hospital Medical School, vice Mr. Benjamis Moore, who was recently elected to the newly established chair of Biological Chemistry at the University College, Liverpool.

THE jubilee of Sydney University was celebrated on October I, when addresses of congratulation were presented from British colonial and foreign universities. The Australian universities were represented in an address by Prof. Tucker, and Prof. Baldwin Spencer, F.R.S., spoke for the English universities.

RFFerring to the Education Bill, in a letter in Monday's Times, Sir Henry Roscoe favours the view first stated in NATURE, namely, that the part of the Bill dealing with secondary education should be dealt with separately and passed before taking that concerned with primary instruction. Since this suggestion was made in these columns, excitement over the religious difficulty involved in the representation clause of the Bill has grcatly increased, and there seems little hope that a compromise will be effected between the contending clerics. It is now clear that the Government would have been well advised to have divided the Bill into two and settled secondary education apart from primary education. As Sir IIenry Roscoe remarks, "To the mind of the nation at large, the question as to whether children are to be taught the Catechism or not looms small in comparison with that as to whether the next generation can be better prepared than our own to sustain and improve the industrial and commercial position of the Empire." Whatever may be thought about religious instruction in primary schools, it is unreasonable to delay the coordination of secondary education until the various parties have settled their differences, more particularly as public opinion is in favour of placing secondary education on a sound basis as soon as possible.

Mendel's Theory of Heredity. By F. A. D. . . . 573

Lightning Arrestors in Electrical Engineering. By C. C. G.

Our Book Shelf :-

"Catalogue of Scientific Papers (1880-1883), Supple-

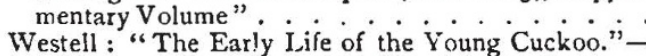

R. L. "Physics : a Text-book for Secondary Schools." S. S.

Carvallo: “L'Électricité (déduite de l'Expérience et ramenće au Principe des Travaux virtuels)"; Mendelssohn: "Les Phénomènes électriques chez les Etres vivants"

Carmody: "Flementary Chemical Analysis. Distinguishing Tables and Tests"........

Letters to the Editor:-

"The Primrose and Darwinism." - Author of "Primrose and Darwinism"; The Writer of the Review .

A Method of Treating Parallels.-W. R. Jamieson Symbol for Partial Differentiation.-A. B. Basset, F.R.S.

Bipedal Locomotion in Lizards. - N. Annandale $^{\circ}$

A Possible Meteor Shower on October 4.-G. Percy

Fall of a Meteoric Stone near Crumlin (Co. Antrim) on September 13. (Illustrated.) By W. H. Milligan; Dr. L. Fletcher, F.R.S

Opening Addresses at the Medical Schools. By

F. W. T. . . . . . . . . . . . .

The Scientific and Technical Exhibits at the Royal

Photographic Society's Exhibition.

The British Association at Belfast :-

Section K.-Botany.-Opening Address by Prof. J. Reynolds Green, M.A., Sc.D., F.R.S., President of the Section.

Section I.-Educational Science--Opening Address by Prof. Henry E. Armstrong, LL.D., Ph.D.,

V.P.R.S., President of the Section . . . . . . University and Educational Intelligence... .600 